\title{
First Came Economic Cooperation
}

\author{
The Genesis of the Nexus
}

To appreciate the relationship between the international trade and environmental regimes and to understand why it took the particular shape and form that it did, it is important to explore the original goals and intentions of their respective founders. The multilateral trading system grew out of the traumatic events that unfolded during the period between World War I and World War II. A strong desire for peaceful relations among states, and the United States (US)' abandonment of its previous isolationism in favor of a leadership role in global affairs $^{1}$ fostered support all around the world for international economic cooperation, which was seen as fundamentally linked to international peace and stability. Only after the creation of this very first form of cooperation, when large numbers of people were finally free from the immediate obligation of protecting themselves and their families from wars and finding food and shelter, the international community could begin to consider new issues worthy of cooperation. It was against this backdrop that delegates from 113 countries gathered in Stockholm in June 1972 to discuss, for the very first time, what to do with the world's rapidly deteriorating environment, and to lay the foundations for the future development of international law in this area.

The Anglo-American discussions on economic cooperation, which led after only a handful of years to the signing of the General Agreement on Tariffs and Trade (GATT), as well as the early years of the environmental movement, took place in a unique period in history, when a few individuals had enormous influence over the shape of international relations and international law. Men like Cordell Hull, Woodrow Wilson, Theodore Roosevelt, and Clair Wilcox, on one side of the Atlantic, and Winston Churchill, James Meade, and Lionel Robbins, on the other, played a crucial role in shaping the international trade regime. ${ }^{2}$

1 Douglas A. Irwin, Petros C. Mavroidis, and Alan O. Sykes, The Genesis of the GATT (Cambridge University Press, 2008), p. 5 .

2 The focus on the United States is explained by its unique economic power, which "created an inevitable leadership role" so that "the trade system set up under the GATT was no exception, for it incorporated many of the ideas for post-war trading relations generated in the US government during the war." Gilbert R. Winham, International Trade and the Tokyo Round Negotiations (Princeton University Press, 1985), p. 3o. Indeed, as already pointed out in the introductory chapter, the US did provide unique economic leadership during the 1940s. 
Similarly, individuals like Maurice Strong, Barbara Ward, Edmund Muskie, and Stewart Udall, among many others, can be seen as the founders of environmental law and cooperation. Their leadership, foresight, and willingness to look to the future when offered the opportunity to make seminal change, proved critical to the development of international law and cooperation in these areas.

The chronological unfolding of these events is at the root of the particular shape that the relationship between trade and environmental law took at its very beginning. When the protection of the environment became an issue worthy of international cooperation and regulation, the multilateral trading system was already well established: as a late-comer, the 'environment issue' had to be framed and further developed within an already existing legal framework and well-oiled institutional machinery, originally thought of and designed to deal with peace and economic relations alone.

\title{
The Moral Value of Trade and the Need for International Trade Cooperation
}

\begin{abstract}
All the nations of the world are afflicted with many conditions in common.... All the nations are equally interested in restoring the structure of international trade, now prostrate. ... The necessity for some degree of cooperation is patent to every intelligent person, if we are to make satisfactory progress back to a stable and sound business recovery. ${ }^{3}$

CORDELl HUll, Address to the Senate, May 19, $193^{2}$
\end{abstract}

The conditions that afflicted "all the nations of the world" when Senator Hull made this statement on the floor of the Senate on May 19, 1932, included, among others, the disruption of world trade that had followed the Great Depression. The epidemic wave of protectionism, isolationism, and beggarthy-neighbor policies that were at the very root of the contraction of world trade had been set in motion by the adoption in 1930 in the United States of the Smoot-Hawley Tariff Act, ${ }^{4}$ which had pushed the average US import tariff to near-record levels, spurring retaliatory trade actions in a number of other countries. In France, the tariff was compared to a declaration of war, while a British newspaper compared it to the German attack of $1914 .{ }^{5}$ A statement

375 Cong. Rec. 10, 10,639 (May 19, 1932) (statement of Sen. Hull).

4 Tariff Act of 1930, 19. U.S.C. 4.

5 Percy W. Bidwell, 'The New American Tariff: Europe's Answer' (1930) 9(1) Foreign Affairs 1326. Bidwell describes the general European reaction to the Smoot-Hawley tariff as "disapproval, immediate, undisguised, and unanimous." 
signed by 1,028 economists featured on the front page of the New York Times asking President Hoover to veto the bill, protested that higher tariffs "would inevitably inject [bitterness] into our international relations [as they] plainly invite other nations to compete with us in raising further barriers to trade."6 Nevertheless, the tariff came, and it did so at a critical juncture, helping undermine the first fragile multilateral efforts to reduce trade barriers.

Not only had the United States refused to join the League of Nations, but was now actively undermining the League's efforts to negotiate a multilateral tariff truce: "America had brought the world to the brink of international commercial collapse," and it was now the turn for "an American to reverse the process." The American in question was one of the few individuals who had enormous influence over the shape of US postwar policy and who, having witnessed the interwar debacle, made it his lifetime mission to reduce trade barriers through negotiations and restore world trade to its previous flourishing condition. ${ }^{8}$ The American in question was a Congressman from Tennessee who, just one year after his statement on the floor of the Senate, became America's longestserving Secretary of State, holding that office from 1933 to 1944. The American in question was Senator Cordell Hull.

\section{1 \\ The Senator from Tennessee and the International Dimension of Trade Policy}

Born on October 2, 1871 in Overton County, Tennessee, on the border line between the North and the South during the Civil War, and son of a Democrat "of the strictest sect," Hull was always a low tariff proponent. ${ }^{9}$ He perfectly fit the pattern for Democrats not just at that time but from the earliest days of the Republic, when Democrats advocated low tariffs, drawing their support from the agrarian South where farmers produced staple crops for export, and Republicans defended high protective tariffs, drawing theirs from the industrial North where manufacturers faced foreign competition. ${ }^{10}$ Despite being

672 Cong. Rec. 8,328 (May 15, 1930). See Douglas A. Irwin, Clashing Over Commerce (The University of Chicago Press, 2017), p. 387.

$7 \quad$ William J. Bernstein, A Splendid Exchange. How Trade Shaped the World (Atlantic Monthly Press, 2008), p. 352.

8 Irwin, Clashing Over Commerce (n 6) 420; Irwin, Mavroidis, and Sykes, The Genesis of the $\operatorname{GATT}(\mathrm{n} 1) 27$.

$9 \quad$ Cordell Hull, The Memoirs of Cordell Hull (Macmillan, 1948), pp. 3, 7.

10 Irwin, Clashing Over Commerce (n 6) 21-22. The existence of different economic interests within a given society and their influence on government policy had been observed by James Madison in Federalist 10, where he prophetically noted that "[a] landed interest, a manufacturing interest, a mercantile interest, a moneyed interest, with many lesser interests, grow up of necessity in civilized nations, and divide them into different classes, 
a pro-trade Southern Democrat, Hull was not simply acting on behalf of economic interests. It was rather his attachment to certain ideas that became critical to moving trade policy in a new direction. He soon became a firm believer in the importance of low tariffs for the growth of world peace and, insisting on the international reach of domestic trade policies, a vocal advocate of international cooperation on trade and tariff matters.

Trained as a lawyer, Hull started studying tariffs in 1888, when the Mills Bill was pending in Congress. ${ }^{11}$ As a young congressman, he had been advised by more experienced politicians that without a specialization he would get nowhere in the Capitol. He then soon decided to specialize in "revenue, tariff, and other forms of taxation, economics and finance,"12 following the steps of his political mentor and fellow Tennessean, Congressman Benton McMillin, who fought excessive high tariffs on the Ways and Means Committee for many years.

Even before becoming a congressman, Hull had "breathed in the fire of great tariff battles," ${ }^{13}$ such as those surrounding the Mills, McKinley, Wilson, and Dingley Bills. In those years, tariffs were treated as a purely domestic matter. The objective of tariff policies was raising revenue for the government or restricting imports to protect domestic producers from foreign competition, ${ }^{14}$ and Congressional debates boiled down to what policy was more beneficial for American producers and American workers, depending on what domestic interests one was defending. ${ }^{15}$

actuated by different sentiments and views ... The regulation of these various and interfering interests forms the principal task of modern legislation, and involves the spirit of party and faction in the necessary and ordinary operations of the government." The Federalist No. 10 (James Madison).

11 The Bill, which proposed a downward revision of existing tariff rates, after passing in the House in July 1888 , was eventually rejected by the Republican-controlled Senate.

12 Hull, Memoirs (n 9) 46.

13 Ibid., p. 83 .

14 Douglas Irwin identifies three principal objectives pursued by US trade policy. The first two objectives-raising revenue for the government and restricting imports to protect domestic producers from foreign competition-have been pursued respectively until the Civil War and until the Great Depression. It was only after 1929, that he finds the objective to have become 'international': concluding reciprocity agreements to reduce trade barriers and expand exports. Irwin, Clashing Over Commerce (n 6) 2.

15 Grover Cleveland precisely referred to 'our people' as the beneficiaries of lower tariffs, as quoted in Tom E. Terrill, The Tariff, Politics, and American Foreign Policy (Greenwood Press, 1973), pp. 196-97, and in Carolyn Rhodes, Reciprocity, U.S. Trade Policy, and the GATT Regime (Cornell University Press, 1993), p. 27. See also 21 Cong. Rec. 4,250-53 (May 7, 189o), as quoted in Alfred E. Jr. Eckes, Opening America's Market: U.S. Foreign Trade Policy Since 1776 (University of North Carolina Press, 2000), pp. 71, 73 . 
The method of tariff-setting itself reflected the domestic dimension of tariff policy. Tariff bills were largely the result of the pressure of special interest lobbyists, ${ }^{16}$ as it had been from the earlier times of the Republic. Even the ferocious attacks against high tariffs and the corrupt politics and special interests that operated behind the scenes were based on their domestic impacts. One of the strongest attacks came from the well-renowned journalist Ida Minerva Tarbell, who had already established herself as America's first great woman journalist. Tarbell, who had a few years earlier exposed the 'Mother of all Trusts', Rockefeller's Standard Oil, ${ }^{17}$ set upon the mission to expose the negative impact of protection on American working families. In her article Where Every Penny Counts, Tarbell "popularized the notion that protection inflated the profits of manufacturers while raising the cost of living and reducing the standard of living of working families."18

The domestic dimension of trade policy permeated every aspect of US society, from Congressional debates, to newspapers' headlines and public opinion, while there was "little or no thought of their effect on other countries."19 Of course, whenever Congress introduced higher tariffs, Europe would not sit still. Rather, such high tariffs would make Europe, and particularly Britain and France, "deeply indignant."20 Britain's decision to establish a trade bloc with tariff preferences with the British Empire, for instance, was the result of the high tariff rates provided for by the McKinley Bill. ${ }^{21}$ Yet, no one in the United States seemed to give credit to the significant international consequences of American trade policies. ${ }^{22}$

16 In his 1909 scathing article, The Tariff Make-Believe, Wilson argued that "the process by which such a bill is made is private, not public; because the reasons that underlie many of the rates imposed are private" (at 536). See also Raymond Leslie Buell, "The Hull Trade Program and the American System' (1938) New York, N.Y., Foreign policy Association, in cooperation with National peace conference, 13 .

17 Ida M. Tarbell, The History of the Standard Oil Company (McClure, 1904).

18 Irwin, Clashing Over Commerce (n 6) 312.

19 Hull, Memoirs (n 9) 83.

$20 \quad$ Ida Tarbell, The Tariff in Our Times (MacMillan, 1911), p. 7.

21 Irwin, Clashing Over Commerce (n 6) 269.

22 Exceptional in this sense had been the efforts of James Blaine. Once an ardent protectionist, this Republican from Maine soon became aware of the link between domestic and international trade and began advocating reciprocity as a new approach to trade policy, in particular when negotiating trade agreements with Latin America. For instance, in a letter he wrote to McKinley during the drafting of the McKinley Act, Blaine stressed that certain elements of the tariff should be reconsidered as they would be "a slap in the face of the South Americans, with whom we are trying to enlarge our trade." As quoted in Tarbell, The Tariff in Our Times (n 20) 204. 
Even Hull's strenuous fight for lower tariffs in his early years in Congress ${ }^{23}$ was largely driven by their immediate domestic effects-mainly higher costs of living for American citizens. Hull's drive to study the interrelation of trade throughout the world was first inspired by his long Sunday afternoon discussions with Connecticut Republican, Ebenezer J. Hill, whom he met when he first moved to Washington and settled for a long period of time at the Cochran Hotel. At the corner between Fourteenth and K Streets, the Cochran was very popular among Senators and Representatives, and Hill was one of them. ${ }^{24}$ He and Hull would sit for hours on one side of the hotel lobby discussing all kinds of legislative questions, including tariffs. Hill had traveled the world between 1907 and 1910 to study tariffs, bringing back with him endless reports of economic conditions overseas. Inspired by these discussions, and later by the outbreak of World War I, Hull continued studying tariffs and trade questions abroad, and became the most vocal advocate of international cooperation on trade matters. Yet, his remained for many years an isolated voice, as President Hoover, in the 193os, still referred to tariff policy as "solely a domestic question." 25

\section{2}

'When Goods Don't Cross Borders, Soldiers Will'26

World War I was the event that most significantly enlarged Hull's views on trade and tariffs from the national to the international theatre. The 'Great' War played a dual role in Hull's life: as he confessed in his Memoirs, "disastrous as it was in all aspects, [it] offered both tragedy and a springboard for constructive legislation" 27 :

When the war came in 1914, I was very soon impressed with two points. The first was its terrific commercial impact on the United States. I saw that you could not separate the idea of commerce from the idea of war and peace ... And the second was that wars were often largely caused by economic rivalry conducted unfairly. I thereupon came to believe that if we could eliminate this bitter economic rivalry, if we could increase

23 Already in his maiden speech in March 1908, Hull "made a vigorous attack on the high tariff and the monopolies and trusts that grow up behind it ... the protective tariff ... the king of evils, our present tariff, should be given a place near the center of the stage." Hull, Memoirs (n 9) 52 .

24 Ibid., p. 47.

25 Pub. Papers 1932, 2015-7, as quoted in Irwin, Clashing Over Commerce (n 6) 409.

26 This phrase, commonly attributed to Bastiat, was most likely coined by Otto T. Mallery in his book Economic Union and Durable Peace.

27

Hull, Memoirs (n 9) 75 . 
commercial exchanges among nations over lowered trade and tariff barriers and remove unnatural obstructions to trade, we would go a long way toward eliminating war itself. ${ }^{28}$

As a matter of fact, after the outbreak of the war, Hull embraced the philosophy he ended up carrying throughout his 12 years as Secretary of State that trade had a fundamental international dimension, and that "unhampered trade dovetailed with peace [while] high tariffs, trade barriers, and unfair economic conditions, with war." ${ }^{29}$ In his memoirs, Hull explained:

Though realizing that many other factors were involved, I reasoned that, if we could get a freer flow of trade-freer in the sense of fewer discriminations and obstructions-so that one country would not be deadly jealous of another and the living standards of all countries might rise, thereby eliminating the economic dissatisfaction that breeds war, we might have a reasonable chance for lasting peace. ${ }^{30}$

The idea of a positive link between free(er) trade and peace had a long intellectual lineage. In his seminal piece, De l'esprit de lois, Montesquieu had, already in 1748, expressed very clearly the idea that the natural effect of commerce is to lead to peace: "deux nations qui négocient ensemble se rendent réciproquement dépendantes: si l'une a intérêt d'acheter, l'autre a intérêt de vendre; et toutes les unions sont fondées sur des besoins mutuels." ${ }^{31}$ As the most influential exponent of the doctrine of the doux commerce, he firmly believed that commerce polishes and softens barbarian ways: "c'est presque une règle générale que, partout où il y a des mœurs douces, il y a du commerce; et que partout où il y a du commerce, il y a des mœurs douces." ${ }^{32}$ A century later, John Stuart Mill expressed the very same idea defining "the great extent and rapid increase of international trade" as "the principal guarantee of the peace of the world,"33 while Richard Cobden argued, in his Political Writings, that "the more

\footnotetext{
28 Ibid., p. 84 .

29 Ibid., p. 81.

30 Ibid.

31 Montesquieu, De l'esprit de lois (1748), Xx, II. See also Albert O. Hirschman, The Passions and Interests (Princeton University Press, 1977), p. 80; and Robert Howse, 'Montesquieu on Commerce, Conquest, War, and Peace' (2006) 31(3) Brooklyn Journal of International Law 1.

32 Montesquieu, De l'esprit de lois (n 31) Xx, I.

33 John S. Mill, Principles of Political Economy (Longman Green, 19o9), p. 582. See Douglas A. Irwin, 'Trade Liberalization: Cordell Hull and the Case for Optimism' (2008) Council on Foreign Relations, 6.
} 
any nation traffics abroad upon free and honest principles, the less it will be in danger of wars." ${ }^{34}$

Hull was well acquainted with the work and ideas of these intellectuals. The experience of the War brought all these ideas to the surface and fortified a wheel that was already in motion. More importantly, he had found someone who shared his vision. The Presidential victory of the Democrat Woodrow Wilson in 1913, right before the outbreak of the War, represented the opening of a new era for Hull. Although he had never met him during the campaign, he had been following Wilson's career for many years, and welcomed his election with contentment as, in his own words, "there was no doubt that Wilson's principles were mine."35

One of the principles they shared was precisely the moral value of low tariffs and free trade and their role in pursuing peaceful international relations. The Third Point of the famous Fourteen Points delivered by Wilson in 1918 before a joint session of Congress as a statement of principles of post-war peace, proposed "the removal, so far as possible, of all economic barriers and the establishment of an equality of trade conditions among all the nations consenting to the peace and associating themselves for its maintenance." ${ }^{36}$ According to Wilson, this not only made economic sense, but it would contribute to reducing commercial tensions that bred political frictions leading to war:

The experiences of the past among nations have taught us that the attempt by one nation to punish another by exclusive and discriminatory trade agreements has been a prolific breeder of that kind of antagonism which oftentimes results in war, and that if a permanent peace is to be established among nations, every obstacle that has stood in the way of international friendship should be cast aside. ${ }^{37}$

After studying the 'peacemaking' role of free trade during World War I and in his relationship with Wilson, Hull continued to vocally advocate for it during all his years as Secretary of State, ${ }^{38}$ and this idea later became the manifesto of

34 Richard Cobden, The Political Writings of Richard Cobden (1903), p. 222 (emphasis in original).

35 Hull, Memoirs (n 9) 69.

36 Woodrow Wilson's Fourteen Points (Jan. 8, 1918).

37 Woodrow Wilson and Arthur S. Link, The Papers of Woodrow Wilson (Princeton University Press, 1966), p. 51:476.

38 In his first address as Secretary of State, Hull declared that "most modern military conflicts and other serious international controversies are rooted in economic conditions, and that economic rivalries are in most modern instances the prelude to the actual wars that have occurred." N.Y. Times, Apr. 30, 1933. 
his tireless campaign in favor of a reciprocal trade agreements program, which he saw as a necessary instrument to peaceful inter-state relations. ${ }^{39}$

\subsection{The Call for an International Trade Conference}

In his famous 1918 speech, President Wilson did more than just advocate for lower tariffs. He set out his vision for a new postwar world based on "national self-determination and international cooperation, bringing secret diplomacy to an end and making World War I 'the war to end all wars." ${ }^{40}$ The centerpiece of his proposal was the creation of a general association of nations, for the purpose of guaranteeing political independence and territorial integrity, thereby preventing future wars. However, while Wilson's vision for the creation of the League of Nations was clear, he did not have an equally concrete plan for the postwar economic order. ${ }^{41}$

Hull, on the other hand, did. On July 8, 1916, speaking of high tariffs to the House of Representatives, he suggested that governments of all commercial nations should convene, after the end of the war, at an international trade conference to "be held in the city of Washington for the purpose of establishing a permanent international trade congress." ${ }^{42}$ According to his speech, the functions of this congress should be to consider

all international trade methods, practices, and policies which in their effects are calculated to create destructive commercial controversies or bitter economic wars, and to formulate agreements with respect thereto, designed to eliminate and avoid the injurious results and dangerous

39 In 1934, he wrote that "the trade agreements program is the first step in a broad movement to increase world trade. Upon this program rests largely my hope of insured peace and the fullest measure of prosperity." Foreign Relations of the United States, 1937, Vol. 1, at 84145. In late 1939, Hull delivered a widely noted address in which he stated that "the trade agreements program should be retained intact to serve as a cornerstone around which the nations could rebuild their commerce on liberal lines when the war ended ... [The trade agreements program] offers a solid basis for the hope that, with peace regained, there will be a good opportunity for completing the work of trade restoration." Hull, Memoirs (n 9) 746-47. In 1941, when it was the time to renew the program a few years later, Hull argued that "a revival of world trade was an essential element in the maintenance of world peace ... without prosperous trade among nations any foundation for enduring peace becomes precarious and is ultimately destroyed." State Department Bulletin, 1943, at 329, 333 .

$40 \quad$ Irwin, Clashing Over Commerce (n 6) 344.

41 Ibid., p. 344-5.

42 Hull, Memoirs (n 9) 82. 
possibilities of economic warfare, and to promote fair and friendly trade relations among all the nations of the world. ${ }^{43}$

For that matter, Hull did more than make a suggestion. A few months before delivering this speech, he had already prepared a resolution calling for an international trade conference and was ready to introduce it to Congress. Before doing so, he asked Secretary of State Robert Lansing for his opinion on the matter and, to Hull's surprise and disappointment, Lansing replied that some of its features risked producing friction with some other countries and asked him to defer its introduction. In the end, the proposal was never introduced to Congress, but Hull never faltered in his belief that an international trade conference-and subsequent agreement—were essential to restoring the structure of international trade.

As he watched with frustration the failure of domestic efforts to convene an international trade conference, Hull carried his vision to the London Economic Conference in 1933. This was the second of a series of conferences sponsored by the League of Nations to discuss trade restrictions and propose concrete solutions for their removal. ${ }^{44}$ The first one had taken place a few years earlier, in 1927, in Geneva, where, despite the call for international cooperation on trade, no concrete steps were taken. ${ }^{45}$ Similarly, despite Hull's hopes and expectations, the 1933 London Conference did not succeed in securing

\section{Ibid.}

44 Interestingly, the Covenant makes no mention of reducing trade barriers. Article 23(e) of the League of Nations Charter merely stated: "Subject to and in accordance with the provisions of international conventions existing or hereafter to be agreed upon, the Members of the League ... will make provision to secure and maintain freedom of communications and of transit and equitable treatment for the commerce of all Members of the League." League of Nations, Covenant of the League of Nations, Apr. 28, 1919, Art. 23(e).

45 One of the core documents prepared for the Conference, the Report of the Trade Barriers Committee of the International Chamber of Commerce (ICC), recommended "the creation, under the auspices of the League of Nations, of a permanent conference in which representatives of the Governments would have the opportunity of meeting regularly, of constantly studying the condition and needs of international trade, as well as the best remedies for existing difficulties; in which the representatives of Governments would be able to draft treaties to satisfy these needs, and arbitrate disputes arising out of the interpretation of treaties already in force." ICC, Report of the Trade Barriers Committee of the International Chamber of Commerce, at 40o. The final report of the Conference, however, merely recognized the importance of the principle of "parallel and concerted action by the different nations," without any further details or concrete plans. League of Nations, Final Report. The World Economic Conference, Geneva, May 1927, C.E.I. 44(1), p. 178. See also Leslie Runciman, 'Note and Memoranda. The World Economic Conference at Geneva' (1972) Economics Journal 465-472. 
international cooperation on trade matters, nor in agreeing on an acceptable method of reducing trade barriers. Once back in Washington, having learned his lesson, Hull provisionally set aside his original proposal for an international trade conference and for multilateral tariff reduction and decided it would be best to try to secure the enactment of a reciprocal trade agreement program in the US, which would allow the bilateral reduction of tariffs on the basis of reciprocity and without having to be submitted to the Senate. On June 4, 1934, the Senate approved the Reciprocal Trade Agreement Act (RTAA) ${ }^{46}$ by a vote of 57-33, and Roosevelt signed it the following week:

At 9:15 on the night of June 12, I watched the President sign our bill in the White House. Each stroke of the pen seemed to write a message of gladness on my heart. My fight of many long years for the reciprocal trade policy and the lowering of trade barriers was won. To say I was delighted is a bald understatement. ${ }^{47}$

On that occasion, Hull reiterated his firm belief in the peace-making qualities of trade, arguing that the trade agreements program was the first step in a broad movement to increase world trade: "upon this program rests largely my hope of insured peace and the fullest measure of prosperity."48 Despite everything, the program, which the League of Nations defined as the "most practical method of curing the world's economic illness, ${ }^{\prime 49}$ could not prevent the outbreak of a new, much bloodier war in 1939. As World War II raged, Hull worked toward expanding the RTAA into a full-fledged, multilateral system of world trade. ${ }^{50}$ Although he retired as Secretary of State in 1944 and was not directly

46 The RTAA introduced three novel features: tariffs could be reduced by as much as onehalf, but only if the United States gained corresponding concessions from other countries; reductions applied to all countries that did not discriminate against the United States; and agreements could be negotiated without their having to be submitted to the Senate. On the RTAA and its impact on US trade policy, see e.g. Stephan Haggard, "The Institutional Foundations of Hegemony: Explaining the Reciprocal Trade Agreement Act of 1934' (1988) 42(1) International Organization 91; Douglas A. Irwin, 'From SmootHawley to Reciprocal Trade Agreements: Changing the Course of U.S. Trade Policy in the 193os', in Michael D. Bordo et al. (eds.), The Defining Moment. The Great Depression and the American Economy in the Twentieth Century (NBER, 1997) p. 325; Kenneth W. Dam, 'Cordell Hull, the Reciprocal Trade Agreement Act, and the WTO: An Essay on the Concept of Rights in International Trade' (2005) 1 New York University Journal of Law and Business 709 .

47 Hull, Memoirs (n 9) 357.

48 Irwin, Clashing Over Commerce (n 6) 447.

49 Hull, Memoirs (n 9) 518.

50 Irwin, 'Trade Liberalization' (n 33) 7-8. 
involved in the GATT negotiations, he was able to give "the State Department a strong and lasting intellectual direction," ${ }^{251}$ which contributed greatly to the success of the subsequent trade negotiations. After retiring, he watched with "profound gratification" the successful conclusion of the Geneva Conference that led to the adoption of the GATT, noting that "the nations which participated in the negotiations have made a long stride toward the goal of economic betterment and world peace. ${ }^{52}$

\subsection{Anglo-American Trade Collaboration: The Atlantic Conference}

For Hull's vision of a multilateral trading system to get one step closer to reality, one has to look across the Atlantic, to the Economic Section of the United Kingdom (UK) War Cabinet Secretariat. Here, the Oxford economics professor James Meade started drafting the first concrete proposals for a post-war trading system. As Ernest Penrose, an economic adviser at the American Embassy in London at the time, wrote, "if any one event can be designated as marking the origin of the International Trade Organization proposed at Havana in 1947, it took place in Whitehall in the latter part of 1942" and "if any one person can be described as the originator of the movement for an International Trade Organization it is James Meade. 53 Of course, Meade was not alone in these efforts. In London he was surrounded by other economists of the Economic Section of the War Cabinet, in particular Lionel Robbins, Sir John Anderson, and Sir Percival Liesching, and worked alongside Will Clayton, Dean Acheson, Harry Hawkins, Clair Wilcox, and others working in the US State Department.

Despite many challenges, this handful of men succeeded in creating a 'charter for world trade, ${ }^{54}$ which would mark the beginning of a long era of cooperation on trade and economic matters not just between the US and the UK but

51 Irwin, Mavroidis, and Sykes, Genesis of the GATT (n 1) 11. James N. Miller, Wartime Origins of Multilateralism, 1939-1945: The Impact of the Anglo-American Trade Policy Negotiations. Ph.D. thesis, Emmanuel College, University of Cambridge (2003), as quoted in Irwin, Mavroidis, and Sykes, Genesis of the GATT (n 1). As Miller put it, "[Hull] carefully chose a group of men, based upon their views about trade, to formulate his favored policies: if the officials arrived in the Department without decided views, then senior officials quickly inculcated them. Never before had trade policy originated in such a centralized, small, and carefully controlled location. More than any of their predecessors or successors, Hull's men shared several advantages: tremendous power relative to other branches of government, uniformity of opinion and purpose, and the Secretary's passionate commitment to their work and results."

$52 \quad$ N.Y. Times, Oct. 31, 1947, 99.

53 Ernest F. Penrose, Economic Planning for the Peace (Princeton University Press, 1953), pp. 89-9o.

The phrase is borrowed from Clair Wilcox, A Charter for World Trade (Macmillan, 1949). 
among many countries all over the world. This success was possible because it was accomplished at the end of a war, which provided a favorable atmosphere for multilateral action as public opinion could be more easily mobilized. ${ }^{55}$ But the time factor was not the only reason behind this success. The latter was also made possible because the two countries involved in this collaboration were led by men of vision, who were able to surround themselves with a relatively small group of individuals of great intellectual ability, united by a common commitment to international cooperation. ${ }^{56}$ They envisioned the post-war economic system as "a universal system [or] at least a single multilateral system ... rather than a collection of trading blocs. They wanted permanent international institutions to promote cooperation on monetary, trade and development problems." 57

The story of the Anglo-American collaboration on trade matters began precisely with the encounter of two such 'men of vision', a meeting held in complete secrecy in August 1941, on an American cruiser off the coast of one of the bases recently secured by the United States in Newfoundland. The two 'men of vision' in question were the American President F.D. Roosevelt, and the British Prime Minister Winston Churchill, and their secret meeting became later known as the 'Atlantic Conference. ${ }^{58}$

The Atlantic Conference, which resulted in the Charter of the same name, had begun on August 9, 1941, when Churchill arrived in Placentia Bay, Newfoundland, aboard the new battleship Prince of Wales after five days crossing the Atlantic. ${ }^{59}$ A few weeks earlier, his trusted personal adviser, Harry Hopkins, had met with the Prime Minister in the garden of Downing Street to inform him that Roosevelt had expressed the desire to arrange a meeting. ${ }^{60}$ Churchill, having corresponded with the President with increasing intimacy for nearly two years, accepted without hesitation. When he reached Placentia Bay, he was greeted by the impressive sight of several American warships. Roosevelt, who had arrived two days prior, was waiting aboard the cruiser

55 John B. Condliffe, The Reconstruction of World Trade (Norton, 1940), p. 355; Richard N. Gardner, 'Sterling-Dollar Diplomacy in Current Perspective' (1985) 62 International Affairs, 24-5. Jay Culbert, 'War-time Anglo-American Talks and the Making of the GATT' (1987) 10 World Economy 381, 393.

56 Gardner, 'Sterling-Dollar Diplomacy' (n 55) 24-5.

57 Ibid., 22.

58 For an account of the meeting, see Winston S. Churchill, The Grand Alliance (Houghton Mifflin, 1985), pp. 385-400, and Sumner Welles, The Time for Decision (Harper \& Brothers Publishers, 1944), p. 174.

59 Welles, The Time for Decision (n 58 ) 174.

6o Churchill, The Grand Alliance (n 58 ) 381. 
Augusta. All arrangements had been made in deepest secrecy: officially, Roosevelt was on a mid-summer fishing trip on the Potomac and very few knew he had been transferred to the Augusta and was now about to begin one of the most memorable personal encounters of the War. ${ }^{61}$

This meeting was the realization of Roosevelt's long-standing desire to discuss a number of pressing political issues with the British Prime Minister, in particular the question of future policy regarding Japan. ${ }^{62}$ Although the Conference was supposed to be focused on political and war-related matters rather than post-war plans_-considering in particular that on the British side, everything was focused on winning the war-it was "none too early to lay down at least some of the principles by which policies must be guided at the conclusion of the war, to press for a broad program of world economic reconstruction and to consider tentative plans for the application of those policies." 63

As a result, during one of their first conversations on board of the Augusta, Roosevelt proposed to Churchill to "draw up a joint declaration laying down broad principles which should guide our policies along the same road."64 Yet, nothing was said on economic policies at the time and the first draft prepared by Churchill's party contained five general principles, none of which mentioned economic reconstruction or trade. ${ }^{65}$ Only later, as a result of negotiations that were under way during the very same days in Washington concerning the Mutual Aid Agreement, economic considerations crept in: the Fourth Point was added to the Charter, which laid out the foundations of the imminent Anglo-American talks:

Fourth, they will strive to bring about a fair and equitable distribution of essential produce, not only within their territorial boundaries, but between the nations of the world, without discrimination and on equal terms. 66

61 William L. Langer and S. Everett Gleason, The Undeclared War, 1940-1941 (Harper and Brothers Publishers, 1953), p. 664.

62 Ibid., pp. 663, 670. Stewart Patrick, The Best Laid Plans (Rowman \& Littlefield Publishers, 20o8), p. 48; Sumner Welles, Where Are We Heading? (Harper \& Brothers, 1946).

63 This statement has been delivered by Cordell Hull in a radio address, conveying the US government line, as quoted in Harley A. Notter, Postwar Foreign Policy Preparation, 19391945 (Greenwood Press, 1949), pp. 45-46. The Charter was merely a by-product of the Conference. See Richard N. Gardner, Sterling-Dollar Diplomacy in Current Perspective: The Origins and the Prospects of Our International Economic Order (Columbia University Press, 1980), p. 40; Langer and Gleason, The Undeclared War (n 61) 677.

64 Churchill, The Grand Alliance (n 58 ) 385 .

65 For the full text of the first draft of the Charter, see Ibid., pp. $385^{-6}$.

66 Ibid., Fourth Point. 
The phrase "without discrimination and on equal terms" implied the abolition of all Imperial Preferences, and therefore could not be accepted by Churchill. Although a convinced free trader and himself not in favor of Preferences, he did not have the constitutional power to agree to such a commitment on his own. ${ }^{67}$ Under his suggestion, the tone of the fourth point was softened with the addition of the caveat "with due respect for their existing obligations." ${ }^{68}$ This formulation eventually found its way in the final draft of the Charter, which was announced to the world on August 14 as a joint declaration of the two Statesmen.

While the British were relieved, this caveat left Cordell Hull "keenly disappointed", as it seemed to deprive "the article of virtually all significance."69 Nevertheless, the article did contain "a statement of basic principles and fundamental ideas and policies that are universal in their practical application,"70 and it did start an impressive pyramid of collaboration on post-war economic policy between the two powers. The next few years saw a small number of men, on both sides of the Atlantic, build upon the Charter to answer Hull's call for international cooperation on trade. One of these men, the Oxford economics professor James Meade, had just completed a short book entitled The Economic Basis of a Durable Peace, profoundly inspired by Hull's ideas and vision, and was about to embark on a much more challenging project which ended up being the precursor of what would eventually become the GATT.

\subsection{Anderson's Circus}

Meade's colleagues at the Economic Section of the War Cabinet described him as a natural government economist: "he brought a rare clarity of mind, a systematic economic philosophy ... He had a vision of how economics should work and a clear understanding of what made it work as it did." ${ }^{71}$ However, Meade had not begun his education with a focus on economics and was never passionate about economics per se, but rather about what economics could do.

Born on June 23, 1907 in Dorset, he was brought up in the city of Bath in England. His College education at Oxford was concentrated on classics. His

67 Welles, The Time for Decision (n 58) 176; Langer and Gleason, The Undeclared War (n 61) 684 .

68 Churchill, The Grand Alliance (n 58) 388; Irwin, Mavroidis, and Sykes, Genesis of the GATT (n 1) 16 .

69 Hull, Memoirs (n 9) 975.

70 Ibid.

71 Alec Cairncross and Nita G.M. Watts, The Economic Section, 1939-1961 (Routledge, 1989), pp. 54, 113 . 
interest for economics and the decision to move to the newly started School of Philosophy, Politics and Economics found their roots in the Great Depression: ${ }^{72}$ like many others of his generation, he thought that the phenomenon of heavy unemployment in the United Kingdom in the inter-war period was "both foolish and wicked." ${ }^{73} \mathrm{He}$ started pursuing economic theory not as an end in itself but rather as a means for "improving the economic and social organization of the country," ${ }^{44}$ in other words, as a means to "do good." 75

After a short period at Cambridge, in 1931 he returned to Oxford, where he taught until 1937. During those years, he worked alongside a number of brilliant economists, but one in particular, with whom he was going to cross paths for many years, had a special intellectual influence on him: Lionel Robbins. Robbins, nine years older than Meade, ran the Adam Smith Society at Oxford, which Meade attended regularly. ${ }^{76}$ Despite their political differences-Meade was more to the Left and Robbins more to the Right- they had a lot in common. Just like Meade, Robbins had not always intended to be an economist. His first love was English literature and his ambition in life was to become a poet. ${ }^{77}$ The Great Depression and the disillusionment that surrounded the immediate post-war period pushed him to study economics. ${ }^{78}$ Meade and Robbins even had the same mentor, Major C.H. Douglas, who helped shape their conviction that economic theory could be used as a cure for the evil they saw in society, by contributing to the formulation of wise and effective policies.

A few years after their first encounter in Oxford, they found themselves working together in the Economic Section of the War Cabinet. The Section, which became known as 'Anderson's Circus' after the cabinet minister who was in charge, Sir John Anderson, ${ }^{79}$ gathered professional economists, in charge not only of the war economy but, even more importantly, of the preparation of plans for what should happen after the end of the war. ${ }^{80}$ Under Anderson, and thanks to the high-level briefs prepared by its members, the Section became

72 Susan Howson (ed.), Collected Papers James Meade Vı (1st ed., Routledge, 2016), p. 1; David A. Reisman, James Edward Meade, Great Thinkers in Economics (Palgrave Macmillan, 2018), p. 5 . James Meade, Wage-Fixing: Stagflation, Vol. I (Allen and Unwin, 1982), p. 53. Alec Cairncross, 'Economic Forces in a Social Context: James Meade: Obituary', Guardian, Dec. 28, 1995, 12.

75 Reisman, James Edward Meade (n 72) 2.

76 Ibid., p. 10.

77 Susan Howson, Lionel Robbins (Cambridge University Press, 2011), p. 2.

78 Ibid., p. 51.

79 Culbert, 'War-time Anglo-American Talks' (n 55) 388.

8o Lionel Robbins, Autobiography of an Economist (Macmillan, 1971), p. 186. 
an integrated part of the Whitehall machine. ${ }^{81}$ It comprised seven main areas of work and Meade, who had just been pulled from the League of Nations Secretariat where he had been writing their economic survey, was in charge of "finance, exchange and export policy." 82

Robbins and Meade served consecutive terms as directors of the Section, both actively committed to a better post-war world. Mindful of the lessons of their teacher and mentor Douglas, they were both committed to practical and constructive internationalism, convinced that post-war reconstruction could only be built on universal, or at least multilateral economic cooperation.

\subsection{Meade's Multilateral Approach to Trade Agreements}

Just like Cordell Hull, Meade believed that "the causes of international conflicts are economic in character and for this reason only an International Organization which is based upon a stable, just, and efficient economic foundation can hope to succeed in its primary political tasks." 83 In his short volume The Economic Basis of a Durable Peace, Meade advocated for some form of international organization as a necessary prerequisite for the international regulation of economic affairs, which should be based on the principle of free trade. More precisely, he argued for a "gradual approach to free trade," to reduce trade barriers over a series of years rather than removing them altogether. ${ }^{84}$ The arrangement of this gradual reduction of barriers to trade would constitute one of the priorities of the international organization in question. ${ }^{85}$

After joining the Economic Section in 1941, Meade had the opportunity to further develop and polish his ideas, which he eventually fine-tuned in his famous piece Proposal for a Commercial Union. ${ }^{86}$ The Proposal-which envisaged a system where tariffs would be reduced, discrimination removed, and an international institution created to administer disputes-built on the long and rich history of bilateral treaties of commerce whose origin dates back to the middle ages. Treaties of commerce between states made their first appearance in the fourteenth century, thanks to the efforts of the King of England,

\footnotetext{
81 Howson, Lionel Robbins ( $\mathrm{n}$ 77) 387-8.

82 Robbins was in charge of "price and wages;" John Jewkes of "manpower;" Joan Robinson of "production and supply;" P.K. Debenham of "food and consumption;" Alec Cairncross of "shipping and transport;" and Harry Campion of "general statistics." See Alan Booth, 'Economic Advice at the Centre of British Government, 1939-1941' (1986) 29 History Journal $655,659,664$.

83 James E. Meade, The Economic Basis of a Durable Peace (Allen \& Unwin, 1940), p. 11.

84 Ibid., p. 85 .

85 Ibid., p. 18 o.

86 James E. Meade, Proposal for a Commercial Union (1943).
} 
Edward III ${ }^{87}$ Before this time, they simply took the form of unilateral privileges accorded by the sovereign to foreign merchants to ensure their safety on their territory ${ }^{88}$ As time went by, more and more states followed England's example and treaties gradually became increasingly detailed and the legal technique equally improved. More importantly, they crystallized a few essential principles and clauses that became customary in almost all treaties and that came to constitute the core of bilateral regulation of trade. These same principles and clauses found their way in Meade's Proposal many centuries later.

The whole document was centered around the notion of tariff reduction and the prohibition of quantitative restrictions. ${ }^{89}$ These notions clearly recalled the principle of "freedom of commerce" (liberté du commerce), which had characterized treaties of commerce since their inception:

Les parties contractantes s'engagent à n'empêcher les échanges mutuels ou citoyens de chacune des deux parties auront la faculté de venir par aucune interdiction d'importation, d'exportation ou de transit ... ${ }^{90}$

The Proposal further embodied the two traditional guarantees of the principle of free trade, the Most-Favored Nation (MFN) and the National Treatment principles, by forbidding parties to discriminate between foreign products and between foreign and domestic products, ${ }^{91}$ representing two of the traditional

87 The most ancient of such treaties was signed between Edward III, King of England and France, and the maritime cities of the Kingdom of Castilla and the Lordship of Biscay. Boris Nolde, 'Droit et technique des traités de commerce (Volume oo3)', in Collected Courses of the Hague Academy of International Law (The Hague Academy of International Law, 1924), p. 301.

88 An example is provided by the promise made by Henry III of England to the merchants coming from Gotland, Sweden: "quod ... salus et secure veniant in Angliam cum relus et mercandisis suis quas decent de partibus suis Gothlandiae et quod saluo ibi morentur et saluo inde recéedant." Ibid., p. 299.

89 The third principle on which the Proposal was based called Members to "remove altogether certain protective devices against the commerce of other members of the Union and to reduce to a defined maximum the degree of protection which they would afford to their own home producers." Along the same lines, the Proposal forbade Members from imposing quantitative restrictions or prohibitions (clause v).

90 Treaty of Commerce and Navigation, Sweden-Germany, 1911, Martens, N.R.G., 3rd Ser. VIII, 435, as quoted in Nolde, 'Droit et technique' (n 87) 373 .

91 Meade, Proposal (n 86). According to clause (ii), "Members would be bound to give other members of the Union as favourable prices for their produce as they gave for the similar produce from any non-member state." Clause (iv) instead read: "Members would be forbidden to give a preference (whether by tax, subsidy, price offered by state trading body or other means) in price to their home producers which was more than, say, 25 per cent greater than the price offered to similar goods produced by other members of the Union." 
and essential clauses of all modern trade treaties. The MFN clause was introduced for the first time in its modern form in the 1486 Treaty between England and Brittany, ${ }^{92}$ while the National Treatment clause started being introduced during the eighteenth century to put an end to the rapidly spreading mercantilist wars. ${ }^{93}$

Despite being very much imbued with tradition, Meade's Proposal introduced an important innovation, which was immediately endorsed by the Economic Section and later by the Board of Trade: it emphasized the need for a post-war regime of multilateral international trade, rather than one based upon "bilateral barter and preferential trade treatment between particular countries." 94 Treaties of commerce, up until 1943, had been bilateral in nature: although they shared some core principles and clauses, they all differed from one another, sometimes even in the treatment accorded to the parties to the same treaty. ${ }^{95}$ Instead, Meade's underlying idea was to have one single treaty signed by all, or at least a vast majority of states: only then could one talk about a truly international trade regime.

Moreover, this international trade regime would be 'managed' by an International Commerce Commission, an international body with the competence "to interpret the Charter of the Commercial Union, and to arbitrate or to give decisions in case of disputes among its members." ${ }^{96}$ The Proposal covered most of the main points that would become, five years later, the GATT, ${ }^{97}$ while

The MFN clause in the 1486 Treaty between England and Brittany read: "Item, que les marchans d'Angleterre auront et pourront avoir et tenir es villes de Bretagne [sauf les villes de Saint-Malo, Brest et Toucq] et joyront illecques de toutes et pareilles franchises comme les autres marchans estrangiers qui ont entrecours et communication de marchans en Bretagne, et seront traictez aussi doulcement et gracieusement comme les autres nations frécantans en icelui Paiis, villes et lieux d'icelui; et pareillement les marchans de Bretagne auront et pourront avoir et tenir es villes du dit royaume d'Angle- terre, Irland, ville et marche de Calays [sauf les places exceptées par lettres royales] et joyront des dites franchises et aussi seront traités comme dessus est dit des dites marchans d'Angleterre." Nolde, 'Droit et technique' (n 87) 304.

93 States had begun increasing their wealth by reducing imports and increasing exports, adopting protectionist tariffs to protect domestic production and hampering the entry of foreign products. This tariff war gave a whole new meaning to the concept of 'equality' and contributed to the drafting, in all subsequent treaties, of a National Treatment clause. Ibid., p. 306.

94 Irwin, Mavroidis, and Sykes, Genesis of the GATT (n 1 ) 28.

95 There had been a few attempts to 'internationalize' treaties of commerce, but they have all been sectoral, including the sugar conventions of 1902 and 1907, the 1921 Barcelona Convention and Statute on Freedom of Transit, and the 1923 Geneva Convention relating to the Simplification of Customs Formalities.

96 Meade, Proposal (n 86) para. 18.

97 Penrose, Economic Planning (n 53) 94-5. 
the International Commerce Commission was nothing but a precursor of the World Trade Organization.

\subsection{Havana}

Meade's Proposal soon caught the attention of Hugh Dalton, the President of the Board of Trade in the British Government, who saw it as a possible basis for international negotiations. In September 1943, with the Proposal in his pocket, Meade traveled to Washington as part of the Law Commission in charge of discussing trade policy with the Americans. The 'Washington talks on commercial policy' proceeded relentlessly until the summer of 1945. During these two years, Meade, Robbins, and Liesching, the senior civil servant responsible for the Commercial Union in the Board of Trade, discussed trade and commercialpolicy issues with Harry Hawkins, Dean Acheson, and other American officials.

The talks proceeded smoothly and cordially. ${ }^{98}$ Little did Meade know, when he first penned the words 'Commercial Union', that he would be present "on the occasion when they were handed over by the British to the Americans ... or that the Americans would receive them with such welcome."99 By October he reported that

The Americans are drafting a report on Commercial Policy, rather on the lines of our Commercial Union proposals, which is to be jointly agreed with us. Where there are unresolved differences, both views will be expressed. There could not be a more desirable outcome to our deliberations ... Ten years ago at Oxford I should never have dreamed that an economist could live in such a heaven of practical application of real economic analysis! ${ }^{100}$

The idea of liberalizing trade on a multilateral basis, in particular, marked a stark departure from British tradition and was welcomed with enthusiasm by the American delegation. Both countries agreed, without the slightest doubt or hesitation, on the necessity of international cooperation on a greater scale than ever before in the area of trade regulation and policy. This agreement led to the publication, at the conclusion of the two years of talks, of the Proposals for Expansion of World Trade and Employment, as a joint United States-United

98 Lionel Robbins et al., The Wartime Diaries of Lionel Robbins and James Meade, 1943-45 (Palgrave Macmillan Springer, 2014), p. 133.

99 Ibid., p. 111.

100 Ibid., pp. 124, 130 (emphasis in original). See also Irwin, Mavroidis, Sykes, Genesis of the $\operatorname{GATT}(\mathrm{n} 1) 41$. 
Kingdom document, which built on Meade's Proposal and called for an International Conference on Trade and Employment to be convened by the United Nations not later than the summer of $1946 .{ }^{101}$ As a result, GATT negotiations officially kicked off at Church House in London in October 1946.

In London, the US delegation was headed by Clair Wilcox who, nearly 20 years earlier, had organized the famous statement signed by 1,028 economists and featured on the front page of the New York Times asking President Hoover to veto the Smoot-Hawley Tariff Act, and had later become Director of the State Department's Office on International Trade Policy. The UK delegation, headed by H.A. Marquand, a member of Parliament, included, among others, none less than James Meade. This was also the first time that countries other than the United States and the United Kingdom joined in the discussion, submitting drafts and proposals. At the end of the London round, most of the provisions of a draft charter for an International Trade Organization (Iто) were agreed on. It was also agreed that a provisional agreement on international commercial policy, the GATT, would be concluded before the approval of the charter.

After London, negotiators from the participating countries met again in Lake Success, the temporary location of the UN headquarters just outside of New York City on Long Island, and then in Geneva. After a total of 626 meetings, by mid-August 1947 the final text of the GATT and the draft of the charter for an International Trade Organization had been finalized. ${ }^{102}$ These two documents, whose overall objective was to facilitate the flow of international commerce, ${ }^{103}$ represented the "greatest step ever taken toward the establishment, by mutual agreement between governments, of the rules which nations will follow in their conduct of world trade and commerce."104 As President Truman hailed the completion of the General Agreement on Tariffs and Trade, on October 29, 1947, he observed that "never before have so many nations combined in such a sustained effort to lower barriers to trade. Never before have

\footnotetext{
101 U.S. Dept. of State, Proposals for Expansion of World Trade and Employment, State Department Publication No. 2411, Dec. 1945. See also US Dept. of State, Suggested Charter for an International Trade Organization of the United Nations, State Department Publication No. 2598, Sept. 1946.

102 For a detailed account of the meetings and corresponding drafts, see Irwin, Mavroidis, and Sykes, Genesis of the GATT (n 1). The Iто never materialized in the end. See John Jackson, World Trade and the Law of the GATT (Bobbs-Merrill Company, 1969).

103 Woodbury Willoughby, 'American Trade Policy', U.S. Dept. of State Publication 3091, Commercial Policy Series 110 (1948).

104 U.S. Dept. of State, 'A Constitution for World Trade', Publication 2964, Commercial Policy Series 108 (1947).
} 
nations agreed upon action, on tariffs and preferences, so extensive in its coverage and so far-reaching in its effects ..."105

\section{International Cooperation to Protect Our Spaceship Earth}

Approaching 56 hours into their mission, Captain James A. Lovell Jr., Fred W. Haise Jr., and John L. Swigert were only a few hundred thousand miles away from the moon. A massive power failure aboard the spacecraft forced the astronauts to make a drastic change of plans: after swinging around the moon, the crippled Apollo 13 rocketed towards an emergency splash down in the Pacific Ocean on Friday April 17, 1970. As they turned their backs on the moon, the three astronauts were racing against time, trying to reach the Earth before their severely limited reserves of oxygen, electricity, and water ran out. ${ }^{106}$

The crucial problem in those agonizing days of Apollo 13's return from the moon was the uncertain balance between the capacity of the spaceship to support life and the demands made on it by its inhabitants. A month later, then Secretary General of the United Nations, U Thant, told this very same story to the students of the University of Texas. His goal was to spur in them a certain interest and concern for the protection and preservation of the global environment. To this end, he compared the problem faced by Apollo 13 during those last few days to the one faced by our planet Earth - though vaster and more complex. Just like the spaceship, the Earth was struggling to meet the needs of its passengers and to absorb the various waste products they produced: the balance between the life-sustaining systems of the Earth and the industrial, agricultural, technological, and demographic demands of its inhabitants had been lost. ${ }^{107}$

In 1970, when U Thant gave this speech at the University of Texas, the environment was becoming "the most international of all the great issues which have confronted, or are likely to confront, the human race" 108 which would give the East and West a new reason to cooperate. Of course, the East and West had

\footnotetext{
105 Harry S. Truman, Proclamation 2761: Carrying Out General Agreement on Tariffs and Trade Concluded at Geneva (Oct. 30, 1947).

106 John Noble Wilford, 'Crew of Crippled Apollo 13 Starts Back After Rounding Moon and Firing Rocket; Men Appear Calm Despite Low Reserves', N.Y. Times, Apr. 15, 1970.

107 Press Release, Address by Secretary General, U Thant, at University of Texas on 14 May: Human Environment and World Order, UN Press Release s G/sm/1259 (May 14, 1970).

108 Maurice F. Strong, Opening Remarks at Informal Meeting of Preparatory Committee for the Conference (Nov. 9, 1970) (on file with the Environmental Science and Public Policy Archives at Harvard University, Maurice F. Strong Papers, Box 28[283]).
} 
already been cooperating for nearly 30 years on matters of war, peace, national security, and trade. Before 1968, when the UN first decided to call the very first Conference on the Human Environment, the environment was not considered as a global issue except by a few people in a small number of countries, primarily in the industrialized world. ${ }^{109}$ The term 'environment' itself was entirely new to the jargon of public affairs. 'Pollution' was more frequently used, and it was treated as a purely local concern. ${ }^{110}$ The truth is that the 'environment issue' had just been put on the table of national and international decisionmakers, catching them entirely unprepared.

\subsection{The Utilitarian Approach to Environmental Protection}

Of course, man had always interacted with nature: from the time primitive man discovered fire and fashioned his first tools and weapons, his technologies have significantly been affecting the natural environment. ${ }^{111}$ Nature represented both a threat and a resource, and throughout history man has used his technologies and inventions to tame and exploit it. For years, almost all the nations of the world have been preoccupied with economic growth. On the one hand, science and technology seemed to offer the key to ever-expanding material well-being, while on the other, nature seemed to offer unlimited abundance of resources to be exploited.

Accordingly, international treaties signed during the end of the nineteenth and the beginning of the twentieth century were not devoted to the protection of the environment per se, but rather to the exploitation of certain resources, the control of transboundary damage, and the use of shared watercourses, always with economic growth in mind. ${ }^{112}$ In 1902, for instance, eight countries

109 'The Environment: A Global Issue'. Maurice Strong Interviewed by Kurt R. Swinton and 'Maurice Strong: Can Savages Learn Self-Reliance?' Interview for Populi (1972-75) (both documents on file with the Environmental Science and Public Policy Archives at Harvard University, Maurice F. Strong Papers, Box 27[268]).

110 See e.g. United States Senate, History of The Committee on Environment and Public WorksUnited States Senate, S. Doc. No. 100-45 (1988), 11.

111 Maurice F. Strong, Statement to the Economic Commission for Latin America in Santiago, Chile (May 3, 1971) (on file with the Environmental Science and Public Policy Archives at Harvard University, Maurice F. Strong Papers, Box 28[282]).

112 See e.g., London Convention Designed to Ensure Conservation of Various Species of Wild Animals in Africa Which Are Useful to Man or Inoffensive, 19oo C.d. 101, Vol. 56, pp. 825-837; Convention for the Protection of Birds Useful to Agriculture, March 19, 1902, 191 C.T.S.; Treaty for the Preservation and Protection of Fur Seals, June 7, 1911, 37 Stat. 1542; London Convention relative to the Preservation of Fauna and Flora in their Natural State, November 8, 1933, 172 U.N.T.S. 241; Washington Convention on Nature Protection and Wildlife Preservation in the Western Hemisphere, October 12, 1940, 161 U.N.T.S. 193; Washington International Convention for the Regulation of Whaling, December 2, 
signed a convention aimed at protecting certain species of birds. Their protection, however, was only instrumental for the ultimate goal of the convention, which was to foster the countries' agricultural sector, explaining the full title of the document-Convention for the Protection of Birds Useful to Agriculture. Along these very same lines, the United States had a few years prior defended its decision to prevent British vessels from sealing in the Bering Sea in order to prevent over-exploitation of fur seals. ${ }^{113}$ In its argument, the United States explained that the US Government had "an interest, an industry, and a commerce derived from the legitimate and proper use of the produce of the seal herd on its territory, which it is entitled ... to protect against wanton destruction by individuals." 114

Even the notion of 'conservation', which developed in the nineteenth century in the United States through the work of a small number of naturalists and philosophers, ${ }^{115}$ carried with it a certain utilitarian flavor: in his first message to Congress on December 3, 1901, on the question of resource development, Roosevelt had proclaimed that "[f]orest protection is not an end in itself; it is a means to increase and sustain the resources of our country and the industries which depend upon them. The preservation of our forests is an imperative business necessity."116 Along the very same lines, 40 years later, the Atlantic Charter reiterated the importance of equal access to raw materials and natural resources solely to ensure states' economic prosperity.

And the same utilitarian vision characterized those international cooperation efforts, which had their origin precisely in the Atlantic Charter and had

1946, 161 U.N.T.S. 72; Washington International Convention for the North-West Atlantic Fisheries, February 8, 1949, 157 U.N.T.S. 157; Tokyo International Convention for the High Seas Fisheries of the North Pacific Ocean, May 9, 1952, 205 U.N.T.s. 65; International Convention for the Prevention of Pollution of the Sea by Oil, May 12, 1954, 327 U.N.T.s. 3. See Edith Brown Weiss, 'The Evolution of International Environmental Law' (2011) 54 Japanese Yearbook of International Law 1; Pierre M. Dupuy and Jorge E Viñuales, International Environmental Law (Cambridge University Press, 2015), p. 6.

113 Arbitration between the United States and the United Kingdom related to the Rights of Jurisdiction of United States in the Bering's Sea and the Preservation of Fur Seals, August 15, 1983, XXVIII R.I.A.A. 1.002 [hereinafter Bering Sea Arbitration], Argument for the United States before the Tribunal of Arbitration convened at Paris under the provisions of the treaty between the United States of America and Great Britain, concluded February $29,1892$.

114 See Bering Sea Arbitration. See also Lake Lanoux Case (France v. Spain), November 16, 1957, 12 R.I.A.A. 281; 24 I.L.R. 101; Trail Smelter Case (US v. Canada), March 11, 1941, 3 R.I.A.A. 1938.

115 For a historical overview of the conservation movement in the US, see Stewart P. Udall, The Quiet Crisis (Avon Books, 1964).

116 Theodore Roosevelt, First Annual Message, Dec. 3, 1901 (emphasis added). 
led, only a few years later, to the creation of the United Nations. Such efforts were aimed at uniting the nations of the world in the common effort to end wars and resource conservation was seen merely as instrumental in the struggle for peace that motivated the international economic conferences of the 1940s. Precisely because national and international attention was focused on matters of peace, and on the economic integration that made it possible, the protection of the natural environment remained a far less prominent political issue for many years.

\section{2 "We Have Met the Enemy and He Is Us"117}

Then the 196os came, and things began to change. After World War II, while working for the US government, the popular author and biologist Rachel Carson had tried to interest some magazines in an article on the dangers of the pesticide DDT, but all her efforts seemed to be in vain. Ten years later, in 1958, she tried once again to reach out to publishers but, just like before, each and every one of them turned her down. The only exception was the New Yorker, which, in 1962, agreed to publish a series of articles exposing the hazards of DDT. ${ }^{118}$ The pesticide, which had long been regarded as some sort of miracle drug, destroying pests and reducing insects-borne diseases, had been found to do more harm than good, causing wholesale destruction of wildlife and its habitat, and clearly endangering human life. ${ }^{119}$ The articles were later gathered in what became one of the landmark books of the twentieth century, Silent Spring, opening the door to the birth of the environmental movement and helping launch a new decade of rebellion and protest. ${ }^{120}$

117 This quote was printed on a poster to promote Earth Day in 1970 and was later used by Walk Kelly in a famous cartoon strip that caught the collective imagination of Americans and is still used in public discourse to describe negative impacts of human activity on our planet (i.e. global warming). The phrase is deemed to derive from braggadocio during the War of 1812 in which commodore Oliver Hazard Perry reported "we have met the enemy and they are ours" to William Henry Harrison after the Battle of Lake Erie.

118 Rachel Carson, 'Silent Spring-I', New Yorker (June 16, 1962).

119 The example of DDT is just one of many instances where technology introduced to address certain concerns has backlashed and in turn created a whole array of othermore serious-environmental problems. Some of the most striking examples have been gathered in a Special Supplement of Natural History in 1969 and later a book: M. Taghi Farvar and John Milton (eds.), The Unforeseen International Ecologic Boomerang (American Museum of National History, 1969).

120 Rachel Carson, Silent Spring (Houghton Mifflin, 1962). This book was the first of several publications on the adverse impact of human activities on the environment. Other examples include Our Synthetic Environment, published by Murray Bookchin under the pseudonym 'Lewis Herber' in 1962 and The Population Bomb by Stanford professor Paul Ehrlich in 1970 . 
With increasing frequency, television brought images of environmental disasters - such as the 1967 Torrey Canyon oil spill off the British coast and the 1969 Santa Barbara oil spill-into homes all over the world. These catastrophic events created a sense of vulnerability and showed the potentially destructive impact of man's interaction with nature: ${ }^{121}$ while for most human history, the principal threats to man had come from nature, in those years it became increasingly clear that the principal threats to both man and nature were coming from man himself. ${ }^{122}$

From being the concern of a small group of conservationists for the protection of species of wildlife and the natural landscape, the environment had become the concern of many individuals and communities, mostly in industrialized countries, with the local and visible problems of air and water pollution. ${ }^{123}$ Yet, the 'environment issue' was still perceived only as a local problem, to be dealt with nationally. We are still a few years away from the image of 'Spaceship Earth' and the awareness of the 'environment issue' as a truly and intrinsically global issue. It would still be a few years before we would begin to grasp "the complexity of the ecological relationships through which man interacts with his natural environment and the magnitude of the problem he is creating by his interventions in the ecosystems which are vital to his own well-being —indeed his very survival."124

\subsection{Spaceship Earth}

In 1972, the crew of the Apollo 17 mission provided us with 'The Blue Marble', the most powerful image of the Earth seen from outer space-an incredibly beautiful, yet finite and vulnerable, planet which provides the home and safeguards the hopes of humankind. This and other photographs of our blue planet, coming from even earlier Apollo missions, dramatized the unity and

121 The earliest known comprehensive scientific examination of human activity degrading the earth's ecosystems is George Perkins March's classic work Man and Nature: Or Physical Geography as Modified by Human Action, published in 1864.

122 Maurice F. Strong, Address at the National Foreign Trade Convention, The Waldorf Astoria NY: The Crisis of Our Environment and the Quality of Life (Nov. 17, 1971) (on file with the Environmental Science and Public Policy Archives at Harvard University, Maurice F. Strong Papers, Box 28[281]). See also Stewart P. Udall, 'We Must Save the Beauty of Our Land', The Carpenter, Apr. 1964, 2: "Like little gods, we manipulate and mold our natural and physical environment to suit our designs. But, in exercising dominance over nature, we have too often ignored our dependence on nature. The pressures of overpopulation, the sense of rootlessness that accompanies a wheel-happy nation, and the soft-confidence that follows prosperity have all taken their toll on nature."

123 Strong, Address at the National Foreign Trade Convention ( $\mathrm{n} 122$ ).

124 Ibid. 
fragility of the biosphere and contributed to the analogy of the Earth as the planetary life-support system. ${ }^{125}$

At the same time, these photographs conveyed a decisive image of the Earth as spherical and 'closed', signaling a long process of transition in the "nature of the image which man has of himself and his environment." ${ }^{126}$ Largely regarded as the father of the idea of 'spaceship Earth', Kenneth Boulding described this transition as pressing and inevitable. ${ }^{127}$ According to Boulding, the man of the past was unaware of the inherent limits of the world he inhabited. Rather, he imagined himself living in a 'virtually illimitable plane': "[t]here was almost always somewhere beyond the known limits of human habitation ... there was always someplace else to go when things got too difficult."128 If a piece of land suddenly became barren, a forest burned to the ground, or a lake dried up completely, there was always the possibility to find new fertile soil, lush vegetation, and rich bodies of water. This kind of 'open' Earth was picturesquely defined by Boulding as 'cowboy economy', characterized by illimitable plains and countless frontiers man could constantly push back. The 'closed' spherical Earth that photographs of the 'Blue Marble' were showing could instead be better explained by the idea of a 'spaceman economy', "in which the Earth had become a single spaceship, without unlimited reservoirs of anything, either for extraction or for pollution, and in which, therefore, man must find his place in a cyclical ecological system ....".129

Despite the rather 'esoteric' nature of Boulding's thinking, ${ }^{130}$ his ideas of a 'spaceship Earth' rapidly gained traction and soon began to inform all subsequent discussions on the environment. In his last speech before the Economic and Social Council in Geneva, US Ambassador Adlai Stevenson referred to the Earth as a little spaceship on which we travel together, "dependent on its vulnerable supplies of air and soil."131 The same analogy was later recalled by the biologist and philosopher René Dubos and the economist Lady Barbara Ward Jackson, who co-authored a report on the state of the global

\footnotetext{
125 Lynton K. Caldwell, 'A World Policy for the Environment', The Unesco Courier (Jan. 1973), 5.

126 Kenneth E. Boulding, 'The Economics of the Coming Spaceship Earth', in H. Jarrett (ed.), Environmental Quality in a Growing Economy 3-14 (John Hopkins University Press, 1966).

127 See Robert F. Blomquist, " "Clean New World”: Toward an Intellectual History of American Environmental Law, 1961-199o' (1990) 25(1) Valparaiso University Law Review 1, 27.

128 Boulding, 'The Economics of the Coming Spaceship Earth' (n 126) 3.

129 Ibid.

130 Blomquist, '“Clean New World"' (n 127) 27.

131 Adlai Stevenson, 1965, extract from his last speech, as quoted in John McHale, 'The Changing Pattern of Futures Research in the USA', Futures (1973), 258.
} 
environment-entitled Only One Earth - which served as the scientific basis and conceptual framework for the Stockholm Conference. In their words,

We are indeed travelers bound to the earth's crust, drawing life from the air and water of its thin and fragile envelope, using and reusing its very limited supply of natural resources. Now that all habitable parts of the globe are occupied, the careful husbandry of the earth is a sine qua non for the survival of the human species, and for the creation of decent ways of life for all the people of the world. ${ }^{132}$

At the same time, the closed nature of the Earth triggered heated discussions on the impact of the growth of the world's population on its limited resources. In 1968, a small international group of scientists, industrialists, and bankers had formed an organization, named the Club of Rome after the Accademia dei Lincei of Rome, where they held their first meeting. ${ }^{133}$ In 1972, united in their conviction of the gravity of the situation facing mankind, these men produced a report titled Limits to Growth, which addressed the issue of a growing population on the Earth's limited resources, pointing out that this was a global concern. ${ }^{134}$ The scale of the present human population, of its intervention in the natural system, and of the impact of those interventions on that system had grown at such a rate that the historical man-nature relationship had been turned on its head. ${ }^{135}$

A natural consequence of the 'spaceship Earth' idea was the realization that international cooperation was crucial if one were to guarantee its protection and preservation. Environmental problems were finally seen as transcending

132 Barbara Ward and René Dubos, Only One Earth (W.W. Norton \& Company, 1972), pp. xvii-xviii.

133 Alexander King, 'New Ethic for Survival', in Clifton Fadiman and Jean White (eds.), Ecocide-And Thoughts Toward Survival (Center forStudy of Democratic Institutions, 1971).

134 Donella H. Meadows, The Limits to Growth: A Report for the Club of Rome's Project on the Predicament of Mankind (Penguin, 1972). For earlier examples of studies on the impact of population growth on the environment and natural resources, see William Vogt, The Road to Survival (W. Sloane Associates, 1948); Fairfield Osborn, Our Plundered Planet (Little Brown, 1948); and Paul Ehlrich, The Population Bomb (Ballantine Books, 1970).

135 Maurice F. Strong, Montague Burton Lecture: The United Nations Conference on the Human Environment at Stockholm (Jan. 19, 1973) (on file with the Environmental Science and Public Policy Archives at Harvard University, Maurice F. Strong Papers, Box 28[283]). See also Udall, The Quiet Crisis (n 115) 19o. As to the numbers related to the increase in population, see United Nations Conference on the Human Environment, An Action Plan for the Human Environment, A/CONF.48/5 (Feb. 9, 1972) [hereinafter Stockholm Action Plan], 10. 
national boundaries, together with the acceptance of the concept of the environment as embracing the whole series of cause and effect relationships by which man interacts with nature and in doing so affects himself: ${ }^{136}$

The simple truth is that no place on our planet lives alone and no place can deal alone with the pollution of the planet. We are far from one world politically_-but by necessity if not by choice, we are one world environmentally. And the crisis of the environment has made us common victims of a common adversity. ${ }^{137}$

In only a few decades, the environment - the most local of all issues-had suddenly become one of the most international of all issues: if it is true that environmental problems can and should be addressed by national jurisdictions, effective action to cope with the environmental crisis would require an unprecedented level of international cooperation. ${ }^{138}$ To paraphrase what Adlai E. Stevenson once said about making peace, "protecting our environment is not merely a matter of nations looking at each other, but of their looking together in the same direction." 139 The first steps towards this new kind of cooperation were taken by the man who was put in charge of the Stockholm Conference on the Human Environment, a Canadian self-made man involved both in business and in politics. This man was Maurice Strong, and his inspiring and forceful leadership played a crucial role in the success of the Conference, ${ }^{140}$ which has been often referred to as "one of the boldest adventures in international

136 Maurice Strong Defines Many Environment Problems and Seeks Solutions, Delegates World Bulletin, June 2, 1975, 1084.

137 Edmund Muskie, Address at the Conference on International Organization and the Human Environment, New York: An Alliance for Survival (1971) (on file with the Environmental Science and Public Policy Archives at Harvard University, Maurice F. Strong Papers, Box 28[283]). See also Senator Muskie's address at the opening session in Rensselaerville, as quoted in Richard N. Gardner, 'Global Pollution III: U.N. as Policeman, in Environment and the Quality of Life', 54 Saturday Review, Aug. 7, 1971, 5 O.

138 Maurice F. Strong, Address at the University of Toronto Study Conference on The Crisis of the Human Environment and International Action (May 27, 1971) (on file with the Environmental Science and Public Policy Archives at Harvard University, Maurice F. Strong Papers, Box 28[283]).

139 Maurice F. Strong, Address at the International Youth Conference on the Human Environment, McMaster University (Aug. 27, 1971) (on file with the Environmental Science and Public Policy Archives at Harvard University, Maurice F. Strong Papers, Box 28[281]), quoting Adlai E. Stevenson, Looking Outward Years of Crisis at the United Nations. With these words, Swedish Prime Minister Olof Palme described the character of Maurice Strong, an opinion shared by many members of the UN preparatory staff. 'Canadian Praised as Ecologists Meet', The Gazette, Montreal, June 5, 1972, 45 (on file with the Environmental 
cooperation ever attempted,"141 and which represented the first step in what have been now nearly 5 o years of international environmental cooperation.

\subsection{The 'Internationalist' from Oak Lake}

Born in April 1929 in the small town of Oak Lake in rural Manitoba, Maurice Strong was yet another man deeply affected by the events of that year. The Great Depression was indeed one of the great shaping forces in his life, "a calamity visited not just on [his] family but on [his] community and [his] country and on many millions of people around the globe," as he would later describe it. ${ }^{142}$ A very private child, he would mostly keep to himself, finding refuge in nature to the point of creating an emotional connection with the natural environment that never left him. ${ }^{143}$ In school, thanks to the support and encouragement of his teacher and school's principal Clarence 'Curly' Heapy, Strong eagerly devoured books on science to better understand the mysterious processes of nature that so excited and challenged him. ${ }^{144}$ He counted Curly Heapy as one of the two main influences in his life. The other was his mother, who taught him life's true values and left him with a single overriding message: "never hold yourself back from trying to achieve what you want. Always press to the limit."145

Despite his strong interest in natural science, which Strong further pursued when he left Oak Lake to live with the Eskimos looking for adventure, travel, and a closer connection with nature, he never called himself an 'environmentalist'. The word did not even exist at that time, and would not exist for two more decades. What he has always considered himself, though, was a committed 'internationalist'. ${ }^{146}$ When he left home in 1941, while crossing the country to join the merchant marine, Strong picked up a discarded newspaper rustled by the light breeze in a Saskatchewan freight yard and learned about the meeting between Roosevelt and Churchill in the Atlantic. Though still a boy, Strong could barely contain his excitement, as international affairs had long impinged on his consciousness. As soon as he read that Churchill and Roosevelt had met

Science and Public Policy Archives at Harvard University, Maurice F. Strong Papers, Box $42[418])$.

141 Gardner, 'Global Pollution III' (n 137) 47-5o.

142 Maurice F. Strong, Where On Earth Are We Going? (Knopf Canada, 2010).

143 Ibid.

144 Ibid.

145 Ibid.

146 John Hess, 'What We Hope to Accomplish at Stockholm', International Wildlife (MarchApril 1972), 20 (on file with the Environmental Science and Public Policy Archives at Harvard University, Maurice F. Strong Papers, Box 27[268]). 
and had declared that the world was going to be a different place, he knew at once that he had to be part of that endeavor. This single event gave him a whole new purpose in life: he started learning all he could about the League of Nations and followed with great attention the San Francisco Conference and the formation of the United Nations. ${ }^{147}$

It is no surprise that when in February 1970, almost 30 years later, then UN Secretary General U Thant asked him to serve as Secretary General of the UN Conference on the Human Environment, Strong, who at that time was running Canada's foreign aid program, could not refuse. ${ }^{148}$ He saw immediately that the Conference would give him the opportunity to merge his two great passions: international affairs and nature. Moreover, he was a firm believer that the environment was "the most international of all the great issues which have confronted, or are likely to confront, the human race."149 The 1945 San Francisco Conference and the economic conferences of the late 1940s had ensured international cooperation to maintain and nurture peaceful relations between states and economic stability. The stage was set for a new kind of international discussion, and the first step in this direction was taken by Sweden.

\subsection{On the Road to Stockholm}

The busy corridors of the UN headquarters in New York were constantly bubbling and overflowing with all kinds of political murmuring. In 1967, some voices were unquestionably louder than the others: the Swedish delegates were trying to convince other delegations, in particular the US delegates, about the necessity for protective action towards the environment. They had been sent to New York by the Social Democratic Party, while the country was in political ferment. ${ }^{150}$ Back in 1950, the Swedes had noticed that wild birds were dying in unprecedented number, and their death was soon traced to the seeds the birds ate, which were coated in methylmercury compounds. A few years later, a dangerous amount of this same substance was found in eggs and fish and, as a result, 40 lakes in Sweden were closed to fishing. ${ }^{151}$ After organizing an international conference on the methylmercury threat to the natural environment

\footnotetext{
147 Strong, Where On Earth (n 142).

148 Hess, 'What We Hope' (n 146).

149 Strong, Opening Remarks (n 108).

150 John Lear, 'Global Pollution I: The Chinese Influence, in Environment and the Quality of Life', 54 Saturday Review, Aug. 7, 1971, 41-2.

151 By that time, methylmercury spilled from a petrochemical company during the 195os in the Japanese village of Minamata had poisoned and caused an epidemic among those who ate fish caught in Minamata Bay. Ibid., $1-2$.
} 
and human health, the Swedes took it to the UN, as they felt it would be the best forum to deal with the issue. ${ }^{152}$

After negative responses from other delegations, ${ }^{153}$ the Swedish requests found their way into the text of a resolution presented by the Economic and Social Council (ECOSOC), ${ }^{154}$ which was then endorsed by the General Assembly at its 23rd Session, culminating in the decision to convene, four years later, a United Nations Conference on the Human Environment ${ }^{155}$

The Conference, which took place in Stockholm between the 5 and the 16 of June 1972, was one of a kind. It was the first time in history that the "leaders of the nations had gathered together specifically to look at the evidence that had come from the scientific community as to the effects of man's own activities on the future of the human species and to determine what actions were required by the leaders of the governments of the world to deal with the situation." ${ }^{156}$ It was the first time the environment, in its newly acquired meaning, was being discussed at the international level: environmental problems per se were not new, but awareness of the problems was, and Maurice Strong, as the man in charge with organizing the Conference, had to start everything from square one.

He knew the first fundamental step was to gather all the relevant information and documentation on the current state of the environment. In order to do so, it was necessary to obtain the active participation of most-if not allgovernments. Although Strong's goal was to start an international discussion on the 'environment issue', environmental problems were, first and foremost,

152 Lars-Goran Engfeldt, 'The United Nations and the Human Environment-Some Experiences' (1973) 27(3) International Organization, 394.

153 In particular, strong opposition came from the US delegation. The State Department was against spending USD 2 million on " 8 concurrent long-winded discussions on the environment." The attitude of the United Kingdom and France was also initially rather skeptical of the idea of a United Nations Environment Conference, as they rather favored a continuation of sectoral activities within the specialized agencies, fearing developing countries would use "the environmental bandwagon" as a vehicle for more financial assistance from the industrialized countries. The Soviet delegation, instead, supported the initiative since the beginning, stressing the need for international cooperation to successfully solve environmental problems. Similarly, Belgium, Czechoslovakia, Canada, Iceland, New Zealand, Austria, Uganda, Italy and China, among many others, immediately supported the Swedish initiative. See Lear, 'Global Pollution I' (n 150)41-2; Engfeldt, 'The United Nations and the Human Environment' (n 152) 397; Report of the United Nations Conference on the Human Environment, Stockholm, 5-16 June 1972, A/CONF.48/Rev.1.

154 E.S.C. Res. 1346 (XLV) (July 30, 1968).

155 G.A. Res. 2398 (XXIII) (Dec. 3, 1968).

156 'The Environment: A Global Issue' (n 109). 
of a local nature, and the experience of each nation was an essential ingredient to identify environmental problems and provide guidelines for action. ${ }^{157}$ To this end, more than 12,00o pages of documentation were collected by the Conference secretariat, representing "the first global survey of environmental issues and concerns" ever made. ${ }^{158}$

Second, he needed scientists. For years, politicians had been ignoring warnings from scientific circles about the global significance of the threat to the environment caused by man's activities. ${ }^{159}$ Although the Conference was, of course, a conference of political leaders and not a scientific conference, it was almost entirely based on the best possible evidence gathered from the scientific community and it operated at the critical interface between science and politics. ${ }^{160}$ This was indeed the very first time that the scientific community and that of politicians and decision-makers came together in a constructive manner. ${ }^{161}$

Third, he needed to be prepared. And he was. Thoroughly. At that time, it was indeed difficult to think of another UN meeting so meticulously prepared in advance, to the point that one UN official aptly compared the Conference to a marriage ceremony, where most things had been arranged beforehand, and as little as possible was left to change on the date. ${ }^{162}$ When he was appointed Secretary-General of the Conference in September 1970, Strong began an uphill battle, which would last 20 long months. During this time, he worked 18 hours

157 G.A. Res. 2398 (XXIII) and G.A. Res. 2581 (XXIV) (Dec. 15, 1969). A total of 86 Governments submitted national reports outlining their environmental experience and concerns. Besides the national reports, the Conference secretariat received contributions from the United Nations system, intergovernmental organizations, non-governmental organizations, and individual experts.

158 Stockholm Action Plan.

159 Engfeldt, 'The United Nations and the Human Environment' (n 152)394.

160 The political character of the Conference was underlined by its mandate to serve as a practical means to encourage - and provide guidelines for - action by governments and international organizations in the environmental field. Ibid., 395. See Maurice F. Strong, Address before the 24th Session of the International Geological Congress: Science and Society in the Environment Age (Aug. 21, 1972) (on file with the Environmental Science and Public Policy Archives at Harvard University, Maurice F. Strong Papers, Box 29[296]).

161 One might consider the Paris Biosphere Conference of 1968, sponsored by Unesco (in cooperation with the UN, the WHO, FAO, IUCN, and the International Biological Program of the International Council of Scientific Unions) to mark the arrival of international political awareness of the world environmental issue. However, the Biosphere Conference was still technically a meeting of just scientific experts, while the Stockholm Conference, gathered, next to scientists, political representatives of governments. See Caldwell, 'A World Policy' (n 125) 4.

162 Gardner, 'Global Pollution III' (n 137) 47-5o. 
a day, rising each day at 5:30 a.m. and placing his own family on 'a war footing,' as he himself described it. ${ }^{163}$ Among the main obstacles he encountered was the great gap in the knowledge about the global ecosystem: there was so much uncertainty around the complex interactions between the natural order and the manifold activities of man that Maurice Strong once referred to the little that was known as "islands of knowledge in a sea of ignorance."164 Even within the scientific community there was not always common consensus on many environmental problems, although more often than not, the discrepancy of opinions originated not from uncertainties about scientific facts, but from differences in attitudes towards social values. ${ }^{165}$ Indeed, each country perceived environmental issues differently, depending on its level of environmental sensitivity, as well as on its specific stage of social and economic development. In particular, the disparity in the weight placed on environmental issues was especially pronounced between industrialized and developing countries. ${ }^{166}$

As a result, a second difficulty lay in ensuring the participation of the developing world. In 1969, developing nations still viewed the 'environment issue' in relatively narrow terms: as a disease of the rich, mostly limited to problems of air and water pollution and other associated ills stemming from the processes of industrialization and urbanization. ${ }^{167}$ As he traveled to many of these countries during the preparatory process of the Conference, Strong found that the word 'environment' had not yet acquired the weight it already had in more industrialized nations. Yet, he was able to show that the issues the word embraced were of equally real and growing concern for the developing world. ${ }^{168}$ Understanding its importance and sensitivity, Strong made sure that

163 'Strong Confident Environment Talks Will Be a Success', The Intelligencer, June 12, 1972.

164 Press Release, Statement by the Secretary General of the Conference on the Human Environment at the 2nd Session of the Preparatory Committee for the Conference, Geneva, 8 February 1971, HE/2 (Feb. 9, 1971) (on file with the Environmental Science and Public Policy Archives at Harvard University, Maurice F. Strong Papers, Box 28[283]). Precisely for this reason, the Action Plan for the Human Environment, one of the core documents prepared by the Preparatory Committee and submitted to the Conference as a basis to work on, stressed the importance, in parallel with immediate measures, of ensuring new knowledge on a wide array of environmental problems.

165 Ward and Dubos, Only One Earth (n 132) xvii.

166 Mark Edward Foster, 'Trade and Environment: Making Room for Environmental Trade Measures within the GATT” (1998) 71 Southern California Law Review 393, 407-8.

167 Policy-makers in developing countries were not sidetracked by "dreams of landscapes innocent of chimney stacks" when they were stressing the importance of their development agenda, but rather they were prepared to accept some environmental cost to be able to develop. Ward and Dubos, Only One Earth (n 132) xiii.

168 These issues included, for example, "polluted water supplies, degradation of agricultural lands, depletion of wildlife and fisheries and, perhaps most urgent, the problems 
the development-environment issue received a prominent place both in the preparatory work and on the agenda of the Conference itself. He organized a meeting of experts on the topic in Founex, near Geneva, from 4-12 June 1971, and he was able to reconcile seemingly irreconcilable opposing views by emphasizing that the labels 'development' and 'environment' had obscured the essential common nature of the ultimate goals of both, namely the wellbeing of man. ${ }^{69}$

Finally, there was the question of the organizational arrangements for the years after Stockholm: how could the international community be organized most effectively for environmental action? Was relying on the existing UN agencies the best solution? Or did the world need a new framework?170

Grappling with these extremely complex and entirely new questions, after 20 months of extenuating work, everything was ready. ${ }^{171}$ On the night of June 5, 1972, The Swedish Prime Minister Olof Palme and then UN Secretary General Kurt Waldheim officially opened the environment conference with a ceremony at the Opera House. ${ }^{172}$ During the following two weeks, the Conference was held in three places - the Old and the New Parliament Buildings and the Folkets Hus, the modern headquarters of the Swedish Labor Movement—each a few minutes' walk apart in the center of Stockholm. Sitting concurrently

of cities which are growing at rates unprecedented in human history." Maurice F. Strong, Address at the Man and Science Institute, Rensselaerville (May 23, 1971) (on file with the Environmental Science and Public Policy Archives at Harvard University, Peter S. Thacher Papers, Box 32 [279]). See also, on specific environmental problems affecting developing countries, Erik P. Eckholm, 'Cheaper Than Oil but More Scarce', The Washington Post, July 27, 1975, and 'The Deterioration of Mountain Environments' (1975) 189 Science 764; Henry Pelham Burn, 'Packaging Paradise' (1975) 6o Sierra Club Bulletin 25.

169 Conflicts might instead arise at the level of decisions on individual questions. The success of Strong's efforts to include developing countries in the process was later proven by the high participation in the Conference, as well as the fact that they pushed to get UNEP to Nairobi. Engfeldt, 'The United Nations and the Human Environment' (n 152) 402; Delegates World Bulletin (n 136) 1084.

170 See Phillip C. Jessup, 'Do New Problems Need New Courts?' (unpublished paper on file with the Environmental Science and Public Policy Archives at Harvard University, Peter S. Thacher Papers, Box 32[279]).

171 The Preparatory Committee, composed of 27 governments, held four consecutive sessions, the first one in New York from 10 to 20 March 1970; the second one in Geneva from 8 to 19 February 1971; the third one in New York from 13 to 24 September 1971; and the fourth one again in New York from 6 to 17 March 1972. The results of the preparatory process, spread in the four sessions, are reflected in documents A/CONF.48/6 to A/CONF.48/ 11 which constitute individual reports and recommendations in each of the six subject areas of the Conference.

172 'Canadian Praised as Ecologists Meet' (n 140) 45. 
were three committees, dealing respectively with marine pollution, natural resources and the development-environment issue, and the problems arising from the spread of human settlement.

The main goal of the conference was the development of international consensus on certain new principles to guide governments' action. ${ }^{173}$ The Declaration on the Human Environment, circulated after the end of the preparatory process and endorsed in Stockholm on the very last day, represented the first attempt in this direction. Its preparation had been extremely lengthy and difficult, precisely because the members of the Preparatory Committee did not want a mere exercise in rhetoric, a pious statement of goals. They wanted it to mean something, to establish the first strong principles that would ultimately form the basis of international law in this area. ${ }^{174}$ Being the first document of this kind, everything was open for discussion and every suggestion was duly taken into account. Much of the second week of the Conference was devoted to finalizing the drafting of the Declaration and, after five long days of arguing over nearly every single word of the draft, on the last day of the Conference, just before midnight, Strong emerged to announce: "There will definitely be a declaration."175

Although the Conference did not resolve all the major environmental issues - and no one would have expected it to-it did provide world governments "with the first opportunity to consider on a global basis the important implications of environmental problems for their own people."176 Thanks to Stockholm, "to defend and improve the human environment for present and future generations [had] become an imperative goal to be pursued together with, and in harmony with, the established and fundamental goals of peace and of world-wide economic and social

173 Hess, 'What We Hope' (n 146).

174 Maurice Strong ventured the idea of a Declaration that would go beyond a mere inspirational document: "I think we should consider if it might also go beyond this to include the commitment of governments to certain fundamental principles which would provide the basis for their individual and collective approaches to the challenges of the human environment." Strong, Opening Remarks (n 108).

175 'Strong Breaks Back-Stage Deadlock Over UN Declaration on Pollution', Toronto Star, June 15, 1972, 3; 'Canadian Praised as Ecologists Meet' (n 140). See e.g. Louis B. Sohn, 'The Stockholm Declaration on the Human Environment' (1973) 14 Harvard International Law Journal 423; Alexandre Kiss and Jean-Didier Sicault, 'La Conférence des Nations Unies sur l'environnement (Stockholm, 5-16 juin 1972)' (1972) 18 Annuaire Français de droit international 603 ; Jutta Brunnée, 'The Stockholm Declaration and the Structure and Process of International Environmental Law', in Aldo Chircop (ed.), The Future of Ocean RegimeBuilding: Essays in Tribute to Douglas M. Johnston (Martinus Nijhoff, 2009), pp. 41-62.

176 Strong, Address at the University of Toronto (n 138). 
development."177 After many years, the protection of the environment had finally caught up, and had become one of the goals to be pursued through international law and cooperation.

In 1975, in his first address to the Governing Council of the United Nations Environment Program (UNEP), Maurice Strong declared that "almost all governments had recognized the importance of the environment to their national interests and had taken steps to establish national environmental policies and administrations, most as a direct result of the Stockholm Conference."178 In a number of instances, the establishment of Ministries of the Environment or of similar government authorities, and the enactment of environmental laws and regulations, owed much to internationally generated concerns. ${ }^{179}$ This was for example the case of the European Union (EU) (then the European Economic Community or EEC), as it was only after Stockholm that environmental problems started receiving increasing attention at the Community level. In other countries, such as the United States, national environmental movements in the 196os had already planted the seeds for reform, and the international events that took place in the early 1970s simply gave a final push to a wheel that was already in motion.

Either way, legislators quickly had to face the fact that the 'environment issue' was a late-comer on the political and legal arenas: it required the development of new principles and the enactment of entirely new laws, which had to be built within a well-oiled legal framework, and respect the limits imposed by the already existing regulation of economic matters. In the United States, Congress' power to regulate commerce had been an integral part of the Constitution since its adoption in 1787 , while federal environmental lawmaking, lacking a constitutional foundation, started off as entirely dependent and conditional to the Commerce Clause. In the context of the European

177 United Nations Conference on the Human Environment, Stockholm, Sweden, June $5^{-16}$, 1972, Stockholm Declaration on the Human Environment, U.N. Doc. A/CONF.48/14/Rev.1 [hereinafter Stockholm Declaration].

178 'Concept of UnEP as Leader and Catalyst Becoming Reality; Director Reports Progress', Excerpts of Maurice Strong's address to the UNEP Governing Council on 17 April 1975 and of the accompanying report, UN Chronicle (May 1975).

179 Maurice F. Strong, 'The Institutional Aspects of the Environment', May 20, 1972 (unpublished outline on file with the Environmental Science and Public Policy Archives at Harvard University, Maurice F. Strong Papers, Box 28[282]). 
Union, which had been created precisely to cooperate on trade and customs matters, the introduction of environmental regulation faced similar challenges. And at the international level as well, the efforts of Maurice Strong and all the other negotiators in Stockholm had to face the harsh reality: the GATT, and all the bilateral trade agreements signed by countries until then, had been negotiated at a time when the environment was not a public policy issue, and had been drafted completely ignoring it. As a late-comer, the environment was simply 'added' to the already existing legal framework and could only be regulated and protected within the limits and constraints provided by it.

\subsection{Mr. Clean-The Senator from Maine}

Already in 1963, then US Secretary of the Interior Stewart Udall had called for new forms of international cooperation to realize the full potential of natural resources: "geography has always been a global science and conservation must now become a truly global concept if the optimum use of resources is to be achieved." 180 One of the most eloquent environmental leaders of his time, Udall spoke early on about a 'quiet crisis' that required strong and global preservation efforts. A quiet, yet urgent, crisis, as clarified by John F. Kennedy, ${ }^{181}$ which reached a dramatic climax on April 22, 1970, better known as the first Earth Day. On that occasion, millions of Americans took to the streets of major cities all around the country, marching, listening to folk singers and speeches by environmental activists, and waving 'Save the Earth' banners on crowded streets. ${ }^{182}$

The idea for Earth Day had been developed two years earlier by Wisconsin senator Gaylord Nelson, who had casually suggested a national teach-in on the crisis of the environment, drawing on the tactics of the anti-Vietnam War movements. Nelson was convinced that the environmental crisis was "the most critical issue facing mankind, [making] Vietnam, nuclear war, hunger, decaying cities, and all the other major problems one could name ... relatively insignificant by comparison." 183

180 Udall, The Quiet Crisis (n 115) 196, 199. He also pointed out that although "the atmosphere and the oceans are the two resources that are owned by all of the people of the world ... save for a few farsighted treaties, we have no plan of management for these common resources ...".

181 Ibid., p. xii (preface by John F. Kennedy).

182 David Vogel, 'A Big Agenda' (1987) Wilson Quarterly, 51.

183 See 'Environment. The Downing of Earth Day', Time (Apr. 27, 1970). Robert Gottlieb, Forcing the Spring: The Transformation of the American Environmental Movement (Island Press, 2005), pp. 148-9. See also Edward E. C. Clebsch, 'The Campus Teach-in on the Environmental Crisis: 1970' (1970) 34(109) The Living Wilderness, 10. 
Earth Day represented a turning point in American history, marking a radical upsurge in public anxiety about the environment. ${ }^{184}$ It is also commonly regarded as the beginning of American environmental politics. ${ }^{185}$ Just 18 months prior, during the 1968 presidential campaign, environmental issues had received virtually no attention in either party's platform. ${ }^{186}$ But by 1970, a Harris poll found that Americans regarded pollution as "the most serious problem facing their communities"187 and TIME magazine named protection of the environment the "issue of the year," ahead of the Vietnam War. ${ }^{188}$ By 1970, both the Nixon White House and the Democratic-controlled Congress were stressing the need to safeguard the national environment for future generations, ${ }^{189}$ and by 1972, Congress had passed half a dozen sweeping new environmental laws—starting with the National Environmental Policy Act (NEPA)—making the 92nd Congress "the most productive record for environmental protection in the nation's history." 190

Immediately after the singing into law of NEPA, Nixon dramatically proclaimed that "the 1970s absolutely must be the years when America pays its debt to the past by reclaiming the purity of its air, its waters, and our living environment. It is literally now or never." This, he declared, would be "the environmental decade."191 Nixon's zeal for the environment, however, was short-lived

184 Vogel, 'A Big Agenda' (n 182) 53 .

185 Samuel P. Hays, Beauty, Health, and Performance. Environmental Politics in the United States, 1955-1985 (Cambridge University Press, 1989), p. 52. Others rather emphasize the publication of Carson's Silent Spring, the Santa Barbara oil spill, or even the controversy over the proposed construction of the Storm King pumped-storage power plant on the Hudson River.

186 Richard Lazarus, The Making of Environmental Law (The University of Chicago Press, 2006), pp. 53-4.

187 Vogel, 'A Big Agenda' (n 182) 53.

188 Time Vol. 97(1), Jan. 4, 1971. See also Gladwin Hill, 'Environment May Eclipse Vietnam as College Issue', N.Y. Times (Nov. 29, 1970), A1:2; James McEvoy, 'The American Concern with the Environment', in William Burch et al. (eds.), Social Behavior, Natural Resources and the Environment (1972), pp. 214-36.

189 See e.g., 115 Cong. Rec. 26,576 (1969) (remarks of Rep. Rogers); 115 Cong. Rec. 29,069 (1969) (remarks of Sen. Jackson); 116 Cong. Rec. 32,918 (1970) (remarks of Sen. Cooper); 116 Cong. Rec. 42,392 (remarks of Sen. Randolph); Remarks of President Nixon on Signing Public Law 91-604, Dec. 31, 1970, 7 Weekly Comp. Pres. Docs. 11-12 (1971); Environmental Quality: The President's Message to the Congress Recommending a 37-Point Administrative and Legislative Program, 6 Weekly Comp. Pres. Docs. 160 (1970).

190 National Environmental Policy Act of 1969 § 102, 42 U.s.C. $\$ 4332$ (2006) [hereinafter NEPA].

191 Richard Nixon, 'Statement about the Environmental Policy Act of 1969', Jan. 1, 1970. The adoption of NEPA is considered one of the most creative moments in the history of environmental law. See William H. Jr. Rodgers, "The Most Creative Moments in the History of Environmental Law: "The Whats"' (2000) University of Illinois Law Review 1. 
(lasting less than two years) and largely stemmed from political calculation rather than personal ideology. ${ }^{192}$ His environmentalism might have even been a strategy to steal the spotlight from his likely opponent in the 1972 presidential election, a man that has often been defined as America's most important environmental leader and champion, Senator Edmund S. Muskie. ${ }^{193}$

Edmund Muskie was born in Rumford, Maine, on March 28, 1914. For him, being born and raised in Maine played a crucial role in his early interest and later involvement in American environmental law. He described his native state as "a place of great natural beauty, marred by intermittent ugliness."194 The dichotomy between evergreen forests, trout streams, and abundant fields on the one hand, and the "ugly reality" of pollution and despoliation of nature on the other, was set in his mind since he was just a child. As a son of Maine, he was, viscerally, a conservationist, and whenever that natural beauty was threatened, he felt the need to do something about it. Yet, he recalls the 'environment' not being an issue back then:

When I was a boy, we didn't think about 'pollution'. The word wasn't part of our everyday vocabulary, and it was hardly in the public dialogue. If we thought at all about such matters, what we saw appeared to be a necessary balance between jobs and some pollution of rivers; between wide, open, clean spaces, streams, lakes, forests, mountains, and a few less than lovely factories or plants. The beauties of nature were around us [in Maine] in almost pristine form. What development we had [we thought back then] was the price we paid for the economic benefits, even if it defiled the river some. ${ }^{195}$

192 Already in 1972, he vetoed the amendments to the Federal Water Pollution Control Act. Richard Lazarus, 'Senator Edmund Muskie's Enduring Legacy in the Courts' (2015) 67(2) Maine Law Review 240, 240-1. For an account of Nixon's role in these formative years of American environmental law, see J. Brooks Flippen, The Nixon Administration, Politics and the Environment (UnM Press, 1994) and Nixon and the Environment (UnM Press, 2000).

193 Leon G. Billings, 'Edmund Muskie: A Man with a Vision' (2015) 67(2) Maine Law Review 234. Muskie's role in shaping modern American environmental law has been consistently acknowledged by US courts: according to Lazarus, "[f]ederal courts in their opinions have cited the views of Senator Muskie in the enactment of federal environmental statutes in at least 293 separate cases" while the Justices of the US Supreme Court "have cited to Muskie in 22 different cases." Lazarus, 'Senator Edmund Muskie's Enduring Legacy' (n 192) 242.

194 Edmund S. Muskie, Journeys (Doubleday, 1972), p. 79, as quoted in Robert F. Blomquist, 'What is Past is Prologue: Senator Edmund S. Muskie's Environmental Policymaking Roots as Governor of Maine, 1955-58' (1999) 51(1) Maine Law Review 88, 89.

195 Muskie, Journeys (n 194) 79-80, as quoted in Robert F. Blomquist, “"To Stir Up Public Interest”: Edmund S. Muskie and the US Senate Special Subcommittee' Water Pollution, 
When he went back to Rumford after completing his studies, he observed the 'pollution problem' of the Androscoggin River, which ran through his hometown, and the intense pollution of the air from nearby paper mill smokestacks. ${ }^{196}$ This matter inspired Muskie's 1954 gubernatorial campaign and eventually led to the enactments of Maine's first significant water pollution statute. As governor, he began to understand the complexity of the 'environment issue' — which involved so much more than air and water pollution — at a time when no other politician seemed to be genuinely interested in addressing it. ${ }^{197}$ In those years, the protection of certain environmental components was still largely linked to the possibility of their exploitation. Federal regulation of water, for example, which had begun in the late nineteenth century with the adoption of the Rivers and Harbors Acts, had initially been targeted exclusively at "promoting water transportation and commerce."198 It was only after the first half of the twentieth century that the goal of federal regulation started shifting away from an exclusive focus on protecting navigability, and toward a concern for preventing environmental degradation. The shift, which culminated in the passage of the Clean Water Act in 1972, was largely due to the leadership, foresight, and extreme patience and perseverance of Edmund Muskie.

In 1963, after being "the first Democrat ever to be popularly elected in Maine as a United States Senator," 199 Muskie was appointed by Pat McNamara, the new Chairman of Public Works, as chairman of the newly formed subcommittee on air and water pollution. Over the course of two decades as chairman of the subcommittee, Senator Muskie had a hand in crafting the majority of the most important American federal environmental statutes, ${ }^{200}$ earning the informal

Investigations and Legislative Activities. 1963-66-A Case Study in Early Congressional Environmental Policy Development' (1997) 22(1) Columbia Journal of Environmental Law 1,6 .

196 Joel K. Goldstein, 'Edmund S. Muskie: The Environmental Leader and Champion' (2015) 67(2) Maine Law Review 226.

197 Donald Elliot et al., 'Toward a Theory of Statutory Evolution: The Federalization of Environmental Law' (1985) 1 The Journal of Law, Economics \& Organization 313, 327.

198 Sam Kalen, 'Commerce to Conservation: The Call for a National Water Policy and the Evolution of Federal Jurisdiction Over Wetlands' (1993) 69 North Dakota Law Review 873,877 .

199 Robert F. Blomquist, 'Senator Edmund S. Muskie and the Dawn of Modern American Environmental Law: First Term, 1959-1964' (2002) 26 William \& Mary Environmental Law \& Policy Review 5 o9.

200 The major federal environmental protection statutes adopted during the 1970s include: Clean Air Act, 42 U.s.c. $§ 7401$ et seq. (1970); Clean Water Act, 33 U.s.c. § 1251 et seq. (1972); Federal Insecticide, Fungicide, and Rodenticide Act, 7 U.s.c. $§ 136$ et seq. (1972); Noise Control Act, 42 U.s.c. § 4901 et seq. (1972); Coastal Zone Management Act, 16 U.S.C. § 1451 et seq. (1972); Endangered Species Act, 16 U.s.C. § 1531 et seq. (1973); Safe 
nickname of 'Mr. Clean'. ${ }^{201}$ In less than ten years, this "great environmental legislator"202 succeeded in establishing a comprehensive legal framework, that was not anymore limited to water and air pollution but encompassed nearly every aspect of environmental protection and natural resource conservation.

This brief sketch of legislative achievements does not even begin to suggest the difficulties and challenges Muskie and his associates faced during those two decades. One challenge in particular had proven to be especially grueling-namely, the problematic nature of American federalism and the need to work within the constraints provided by the constitutional design for law-making. ${ }^{203}$

\subsection{The Commerce Clause and the Limits to Federal Environmental Law-Making}

The power of the US Congress over interstate commerce is as old as the Constitution itself. It was actually a major motivation for replacing the Articles of the Confederation in the first place. ${ }^{204}$ As recalled by James Madison, "it should never be forgotten, that the great object of the Convention was to provide, by a new Constitution, a remedy for the defects of the existing one [and] that among these defects was that of a power to regulate foreign commerce." 205 Indeed, the poor conditions of American commerce and the proliferating trade rivalries among the states were the immediate provocations for the calling of the Constitutional Convention. ${ }^{206}$ In response to those concerns,

Drinking Water Act, 42 U.s.c. § 300 et seq. (1974); Forest Rangeland Renewable Resources Planning Act, 16 U.s.c. $§ 1600$ et seq. (1974); Toxic Substances Control Act, 15 U.s.C. $\S$ 26o1-2629 (1976); Resource Conservation and Recovery Act, 42 U.s.c. $§ 6901$ et seq. (1976); Federal Land Policy and Management Act, 43 U.s.c. $§ 1701$ et seq. (1976); Surface Mining Control and Reclamation Act, 30 U.s.c. $§ 1201$ et seq. (1977); Outer Continental Shelf Lands Act, 43 U.S.C. $§ 1331$ et seq. (1978).

201 Blomquist, 'What is Past is Prologue' (n 194) 89.

202 See 'Tribute by Senator Ernest F. Hollings of South Carolina', in United States Senate, Edmund S. Muskie: Late a Senator from Maine-Memorial Tributes, S. Doc. No. 104-17 (1996), 3 .

203 Lazarus, The Making of Environmental Law (n 186) 29.

204 Kathleen M. Sullivan and Noah Feldman, Constitutional Law (Foundation Press, 2013), p. 109.

205 Papers of James Madison, 10:29. Indeed, Article 9 of the Articles of Confederation explicitly stated that "no treaty of commerce shall be made whereby the legislative power of the respective States shall be restrained from imposing such imposts and duties on foreigners, as their own people are subjected to, or from prohibiting the exportation or importation of any species of goods or commodities whatsoever," thereby ruling out the possibility to adopt any national trade policy. See Irwin, Clashing Over Commerce (n 6) 52.

206 Sullivan and Feldman, Constitutional Law (n 204) 109. 
the Constitution, Art, I, §8, cl. 3, granted Congress the power "[t]o Regulate Commerce with foreign Nations, and among the Several States, and with the Indian Tribes." 207 As Alexander Hamilton wrote in Federalist No. 22, a central purpose of that grant was to suppress the "interfering and unneighborly regulations of some States" - regulations which, "if not restrained by a national control," would prove to be ever more "serious sources of animosity and discord." ${ }^{208}$ It was hoped that the national commerce power "would help end hostile state restrictions, retaliatory trade regulations, and protective tariffs on imports from other states." 209

It was precisely this power that allowed Cordell Hull to promote the Reciprocal Trade Agreement Act and that served as a constitutional basis for all the treaties of commerce entered into by the United States over the years. This very same power legitimized the presence of the American delegation at Havana in 1947 and during the previous years in the many commercial talks that the US government conducted with Britain.

On the other hand, the Constitution lacked any clear textual foundation for federal environmental protection law: while the power "to regulate commerce among the states" appears among the enumerated powers of the federal government, no reference was ever made to the environment. Furthermore, none of the other enumerated sources provided a ready fit with environmental concerns. ${ }^{210}$ The lack of constitutional foundation is generally explained with the mismatch between the values and premises of a legal regime for environmental protection on the one hand, and the "basic cultural norms of liberty, prosperity, and freedom from governmental restraint upon which the United States was founded and that are embedded in the US Constitution and Bill of Rights."211

\footnotetext{
207 U.S. Const., art. I, § 8, cl. 3 .

208 The Federalist No. 22 (Alexander Hamilton).

209 Sullivan and Feldman, Constitutional Law (n 204) 109.

210 Lazarus, The Making of Environmental Law (n 186) 3o.

211 Ibid., p. 28. See Bruce Yandle, 'Escaping Environmental Feudalism' (1992) 15 Harvard Journal of Law \& Public Policy 517; Roger Pilon, 'Property Rights, Takings, and a Free Society' (1983) 6 Harvard Journal of Law \& Public Policy 165. The Clean Water Act, for example, while affording wetlands previously unavailable protection, was often attacked as authorizing takings of private property without just compensation. See e.g. Flint B. Ogle, 'The Ongoing Struggle Between Private Property Rights and Wetlands Regulation: Recent Developments and Proposed Solutions' (1993) 64 University of Colorado Law Review 573.
} 
Yet, because environmental problems often affect more than one state, ${ }^{212}$ limiting regulation to the state level was not always enough. A possible solution to this problem was sought in an expansive interpretation of the Commerce Clause, based on the "theory that activities adversely affecting the environment have substantial effects on interstate commerce."213 The so-called 'substantial economic effects' test ${ }^{214}$ and the 'stream of commerce' test ${ }^{215}$ had been used since the early years of the twentieth century to expand the scope of application of the clause to legitimize national regulatory authority on a "wide range of problems, not commonly regarded as commercial in character, which vitally affect the national safety and welfare," including environmental protection. ${ }^{216}$ In a 1981 case, the Supreme Court found that the Surface Mining Control and Reclamation Act of 1977 did not violate the Commerce Clause because surface coal mining had substantial effects on interstate commerce: "the commerce power extends not only to 'the use of channels of interstate or foreign commerce' and to 'protection of the instrumentalities of interstate commerce ... or persons or things in commerce,' but also to 'activities affecting commerce.".217 Similarly, the assertion of federal jurisdiction over wetlands under the Clean Water Act was based on the sweeping powers of Congress under the Commerce Clause. The Act recognizes federal jurisdiction only over 'navigable waters' and, traditionally, the test of navigability had been whether "a stream or body of water in its natural state [was] susceptible to use as a highway of commerce."218 On the basis of the 'substantial economic effects' test, the United States Army Corps of Engineers-responsible for the protection of American wetlandshave progressively expanded the definition of 'navigable waters' to include not only those waters that are susceptible for use in interstate commerce, but "[a]ll

212 “... community or state jurisdictions bear little or no relationship to the geographic spread of air pollution." Edmund S. Muskie, 'Role of the Federal Government in Air Pollution Control' (1968) 10 Arizona Law Review 17, 18.

213 Lazarus, The Making of Environmental Law (n 186) 37 (emphasis added).

214 See Houston E. \& W. T. Ry. Co. v. United States [The Shreveport Rate Case], 234 U.S. 342 (1914).

215 See Swift \& Co. v. United States, 196 U.S. 375 (1905).

216 Cushman, 'The National Police Power under the Commerce Clause of the Constitution' (1919) 3 Minnesota Law Review 289, 319. In particular, Congress had used this approach to deal with problems of morality and criminality. See Champion v. Ames [The Lottery Case], 188 U.S. 321 (1903); Hipolite Egg Co. v. United States, 220 U.S. 45 (1911); and Hoke v. United States, 227 U.S. 308 (1913).

217 Hodel v. Virginia Surface Mining Ass'n, 452 U.S. 264 (1981), quoting Perez v. United States.

218 Ogle, 'The Ongoing Struggle' (n 211) 575. 
other waters ... the use, degradation or destruction of which could affect interstate or foreign commerce," which include wetlands. ${ }^{219}$

If, on the one hand, the Commerce Clause has proven essential in legitimizing Congress' environmental law-making power, on the other, this approach makes congressional control dependent on a commercial nexus and, although commerce can be relevant to environmental protection, it is not ultimately this area of law's central concern. Moreover, the Court has not been consistent in its attitude towards congressional action under the commerce power ${ }^{220}$ and has struck down a number of laws precisely on Commerce Clause grounds. ${ }^{221}$ The result has been that, although federal regulation of the environment is generally preferred, it can only be exercised within the strict and uncertain boundaries set by the Commerce Clause. Moreover, the Commerce Clause set yet another limit to environmental regulation, this time at the state level: as Chapter 3 will explain, the US Supreme Court has interpreted the Commerce Clause's conferral of authority to Congress over interstate commerce to create, by negative implication, a limit on state laws that unduly burden interstate commerce, by, for example, protecting the environment (see later the Dormant Commerce Clause).

219 The Corps began expanding the definition of 'navigable waters' after conservation groups brought a suit against them challenging their use of traditional tests of navigability (Natural Resources Defense Council Inc. v. Callaway). On July 25, 1975, the Corps published interim regulations to expand the definition of 'navigable waters' and then published an expanded definition in 1977 .

220 For example, in the early decades of the xx century, the Court frequently struck down national regulatory laws as exceeding the proper scope of the commerce power (See Railroad Retirement Boardv. Alton Railroad Co., 295 U.S. 330 (1935); Schechter Poultry Corp. v. United States, 295 U.S. 495 (1935); and Carter v. Carter Coal Co., 298 U.S. 238 (1936)). Beginning in 1937, the Court started showing great deference to congressional action under the commerce power and for nearly six decades no law was struck down on Commerce Clause grounds. See Sullivan and Feldman, Constitutional Law (n 204) 131. In NLRB v. Jones \& Laughlin Steel Corp, 301 U.S. 1 (1937), Chief Justice HUG HES stated that "[the] Congressional authority to protect interstate commerce from burdens and obstructions is not limited to transactions which can be deemed to be an essential part of a 'flow' of interstate or foreign commerce [but also] if they have such a close and substantial relation to interstate commerce that their control is essential or appropriate to protect that commerce from burdens and obstructions, Congress cannot be denied the power to exercise that control." See also United States v. Darby, 312 U.S. 100 (1941); Wickard v. Filburn, 317 U.S. 111 (1942); Heart of Atlanta Motel, Inc. v. United States, 379 U.S. 241 (1964); Katzenbach v. McClung, 379 U.S. 294 (1964); Perez v. United States, 402 U.S. 146 (1971).

221 In Solid Waste Agency of Northern Cook County v. Army Corps. of Eng'rs, 531 U.S. 159 (2001), the Court preferred to avoid the challenge and narrowly construed the jurisdictional scope of the Clean water Act to avoid constitutional issues regarding the applicability of the Commerce Clause. 


\subsection{The Economic Purpose of Early European Environmental Efforts}

This account of US federal environmental law-making as dependent on Congress' power to regulate interstate commerce may remind the reader of another similar story, that was unfolding on the other side of the Atlantic. On May 9, 1950, then French Foreign Minister Robert Schuman delivered a famous Declaration marking the creation of the European Community of Steel and Coal - the first step towards European integration. The reasons that pushed six European countries to gather in Paris and create the Community were the same underlying the Constitutional Convention in Philadelphia in May 1787 and the post-war Anglo-American talks in 1943-1948: removing unnatural obstructions to trade with a view to preserving and strengthening peace and stability. In fact, in the 1950 Declaration, Robert Schuman proclaimed that "by pooling basic production and by instituting a new high authority, whose decisions will bind France, Germany and other member countries, this proposal will lead to the realization of the first concrete foundation of a European federation indispensable to the preservation of peace."222

This first step was followed a few years later by the creation of the European Economic Community. The Treaty of Rome, which entered into force in 1958, provided for the creation of a single common market in Europe, based on a customs union, the prohibition of restrictions to the free movement of goods, workers, services and capital among the Member States, a competition policy and a common commercial policy, as well as common policies on agriculture and transport. ${ }^{223}$ In less than ten years, Italy, Germany, France, Belgium, Holland, and Luxembourg had succeeded in creating a single, unrestricted Western European market in nearly all goods. And for nearly zo years that was all that mattered.

Just like the US Constitution, the Treaty of Rome did not contain any reference to the environment, and the framers showed no intention to give the Community powers in this area. ${ }^{224}$ It was only after Stockholm that the heads of State of the EEC Member States convened a Summit where they declared that "economic expansion was not an end in itself" and 'non-material' values,

222 'Documents relatifs au projet français de mise en commun des productions de charbon et d'acier et à l'institution d'une Haute Autorité', La documentation française. Notes et études documentaires, No. 1339 (June 13, 1950).

223 Damian Chalmers et al., European Union Law (Cambridge University Press, 2010), p. 12.

224 Maria Lee, EU Environmental Law: Challenges, Change and Decision-making (Hart, 2005), p. 1; Wolfgang E. Burhenne and Thomas J. Shoenbaum, 'The European Community and Management of the Environment: A Dilemma' (1973) 13 Natural Resources Journal 494,496 . 
such as environmental protection, were crucial for the achievement of the objectives of the Community. As a result of the Summit, the following year, the First Program of Action of the European Communities on the Environment was adopted. ${ }^{225}$

However, as the EEC could only act within the limits of the powers conferred upon it by the Treaties and towards its specific objectives, ${ }^{226}$ the adoption of environmental legislation could only be based on an expansive interpretation of the provisions of the Rome Treaty - which contained no reference to the environment — and was therefore constrained by the need to ensure and promote the functioning of the common market. ${ }^{227}$ Three provisions were initially used as a basis for environmental legislation: Article 2, which sets out the objectives of the Community, Article 100, which deals with 'approximation' or 'harmonization' of laws, and Article 235.

Article 235, in particular, provides law-making power where action by the Community appears necessary to achieve one of the treaty objectives, and the treaty itself has not provided for the necessary powers of action. ${ }^{228}$ However, environmental protection was not included among the objectives in the Rome Treaty:

The Community shall have as its task, by establishing a common market and progressively approximating the economic policies of Member States, to promote throughout the Community a harmonious development of economic activities, a continuous and balanced expansion, an

225 Declaration of the Council of the European Communities and of the representatives of the Governments of the member States meeting in the Council of 22 November 1973 on the programme of action for the European Communities on the environment [1973] O.J. C112/1. See Elisa Morgera, 'European Environmental Law', in Alam et al (eds.), Routledge Handbook of International Environmental Law (Routledge, 2012).

226 Principle of conferral or of attributed properties, as set out in Article 5.2 of the EEC Treaty: "Under the principle of conferral, the Union shall act only within the limits of the competences conferred upon it by the Member States in the Treaties to attain the objectives set out therein. Competences not conferred upon the Union in the Treaties remain with the Member States." Treaty Establishing the European Economic Community, Art. 5.2 March 25, 1957, 298 U.N.T.s. 11. [hereinafter EEC Treaty].

227 Morgera, 'European Environmental Law' (n 225).

228 EEC Treaty, article 235 reads: "If action by the Community should prove necessary to attain, in the course of the operation of the common market, one of the objectives of the Community and this Treaty has not provided the necessary powers, the Council shall, acting unanimously on a proposal from the Commission and after consulting the European Parliament, take the appropriate measures." See Burhenne and Shoenbaum, 'The European Community' (n 224) 498. 
increase in stability, an accelerated raising of the standard of living and closer relations between the States belonging to it. ${ }^{229}$

Although some have tried to read into the objective of "an accelerated raising of the standard of living" an implicit reference to the protection of the environment, Community action aimed at the latter would be admissible only to the extent that it contributed to achieving non-environmental goals. Article 100 , on the other hand, was often used to justify directives which, although cloaked in environmental terms, were actually part of a program to harmonize national laws to remove distortions of competition, being adopted pursuant to the so-called 'General Program for the elimination of technical barriers to trade within the Community'.230

It was only with the adoption of the Single European Act in 1986 that the environment was featured among the Community's objectives, and environmental action at the Community level gained a clear and unequivocal legal basis in the text of the treaty. Until then, the Rome Treaty contained no reference to the environment as an objective of the Community and, in this regard, it was not a rare bird. No commercial treaties or trade agreements negotiated and signed before Stockholm — and for a few years after Stockholm as wellshowed any sign of the environment. And neither did the GATT.

\subsection{The Environment Overlooked at Havana}

On January 1, 1948, when the GATT entered into force, international cooperation on trade matters had finally been made official. Twenty-three countries had succeeded in agreeing on a small but powerful set of rules embodied by the agreement: open markets, non-discrimination, institutional stability, transparency, and the use of tariffs, to be gradually reduced, as the sole instrument of protection. ${ }^{231}$

The need to cooperate on trade matters, however, was not the only issue concerning the delegations gathered at Havana. The United States, despite its role as leader, agreed to accommodate demands coming from both the United Kingdom and developing countries. Throughout the long Anglo-American post-war talks, the British had always been very vocal about the difficulties that would face the country after the end of the war. ${ }^{232}$ As a result, a temporary

229 EEC Treaty, Art. 2.

230 Council Resolution of May 28, 1969, 12 O.J. C 76/1 (1969). See Burhenne and Shoenbaum, 'The European Community' (n 224) 499.

231 Culbert, 'War-time Anglo-American Talks' (n 55) 381-2.

232 In his Proposal, Meade advocated the need "to retain the right to impose more general restrictions on purchases of inessential goods or on unnecessary payments abroad so 
exception for balance-of-payment difficulties and related to the liquidation of government surpluses was introduced in the text of the Agreement. ${ }^{233}$ At the same time, a number of less-developed countries, such as Australia, India, China, Brazil, and Chile, wanted to ensure that any agreement reached during the GATT negotiations would not prevent them from using trade restrictions to promote employment and development goals. In London, they presented proposals for the introduction of a "developing country exception" that would allow them to use quantitative restrictions to foster industrialization, ${ }^{234}$ and provisions to this end were introduced in the final text. ${ }^{235}$

The protection of the environment, on the other hand, was not a concern for any of the delegations involved in the drafting of the GATT. It was never discussed during the negotiations, and the word itself was not included in the final draft of the Agreement. Even one of the provisions of the Agreement that are today considered 'environmental'-Article $\mathrm{xx}(\mathrm{b})$ - was not originally drafted with the environment in mind (see Chapter 3). The provision, which in its original formulation covered restrictions "for the protection of public health or for the protection of animals or plants against disease, insects and harmful parasites," had been part of bilateral treaties of commerce since their inception, together with those covering measures adopted for national defense or to organize the parties' internal trade. ${ }^{236}$ The 1904 Treaty of Commerce between Italy and Switzerland, for instance, allowed the parties to introduce export, import, or transit prohibitions in the following circumstances:

i) Dans des circonstances exceptionnelles, par rapport aux provisions de guerre ; ii) Pour les raisons de sûreté publique; iii) Par égard à la police sanitaire et en vue de la protection des animaux, ainsi que des plantes utiles contre les maladies, les insectes et parasites nuisibles ; and iv) Par égard aux monopoles d'État. ${ }^{237}$

long as we are faced with an acute problem of restoring equilibrium to our international balance of payments." Meade, Proposal (n 86) para. 5. See Culbert, 'War-time AngloAmerican Talks' (n 55) 384; Irwin, Mavroidis, and Sykes, The Genesis of the GATT (n 1$) 32$.

233 Chapter III, Section C.2 of the Proposals reads: "Members confronted with an adverse balance of payments should be entitled to impose quantitative import restrictions as an aid to the restoration of equilibrium in the balance of payments."

234 Irwin, Mavroidis, and Sykes, Genesis of the GATT (n 1 ) 79.

235 See GatT, Article XVIII.

236 Nolde, 'Droit et technique' (n 87) 384.

237 Treaty of Commerce between Italy and Switzerland, 1904. Ibid., 378. 
It had become such an inherent component of trade treaties that Clair Wilcox defined what later became Article XX of the GATT as "routine exceptions copied from previous commercial treaties and trade agreements,"238 and even as "almost boilerplate."239 The purpose of such "routine" exception clause was to build safety valves into the system and allow the Parties to pursue certain legitimate domestic policy goals, perfectly in line with the embedded liberalism's vision of the market as 'embedded' in a broader social fabric and of multilateralism as predicated upon domestic interventionism.

Despite the importance of this exception clause, which was regarded as fundamental to strike a balance between the demands of the international economy and those of domestic social groups, it had nothing to do with the environment, at least not in its original formulation. Even the Draft Iто Charter, which was intended to cover many more topics in addition to trade in goods- such as labor, investment, and competition - was never intended to address environmental protection. It was only after Stockholm, and after the first disputes with an environmental dimension were brought to the GATT adjudicative body, that the exception was given an environmental touch. And even then, as the next chapter will show, it is debatable whether it could provide countries with any real space to protect the environment. In fact, when the environment started being introduced in these exception clauses, embedded liberalism, which recognized their importance and value, had given way to the neoliberal thought which quickly became the prevailing ideology in international trade.

\subsection{UNEP and the Organizational Challenge}

The challenge of being a late-comer was not limited to having to shape new environmental norms within the constraints of the existing legal framework, whether at the domestic, regional, or international level. Issues also arose with regard to the choice of the institutional structure to be developed to deal with the 'environment issue'.

Towards the end of May 1971, 40 key decision-makers from governments, international agencies, and the scientific community met for three days in Rensselaerville, New York, under the auspices of the former US Judge on the International Court of Justice, Phillip C. Jessup. This meeting had been organized by the Institute on Man and Science and the Aspen Institute of

238 Wilcox, A Charter for World Trade (n 54) 179.

239 International Trade Organization, Hearings Before the Committee on Finance, Part I, U.S. Senate, 8oth Congress, 1st Session, at 412, as quoted in Steve Charnovitz, 'Exploring the Environmental Exceptions in GATT Article XX' (1991) 25Journal of World Trade 44. 
Humanistic Studies at the former's idyllic headquarters. ${ }^{240}$ For those three days, all the discussions revolved around a fundamental question which, curiously enough, nobody had really given much thought to until then. The question was - what kind of international organizational arrangements will be needed after Stockholm? And it was indeed a crucial and pressing one.

When the 'environment issue' emerged in the late 196os, international organizations already played a vital role in the political structure of international relations and constituted a fundamental vehicle for international cooperation. During the quarter-century since the end of World War II, despite the persistence of vigorous nationalism, the number of intergovernmental organizations had more than doubled and the United Nations had clearly established itself as the principal focal point in this network. ${ }^{241}$ Despite some opposition, ${ }^{242}$ there was hardly any doubt that the UN was the best forum to deal with the newly emerged 'environment issue', and this feeling was shared by the 40 decision-makers gathered in Rensselaerville.

The real question was how to square this new issue within the existing UN machinery. After 25 years since the creation of the UN and many of its specialized agencies, any proposal had to necessarily come to terms with the existence of quite a large number of international organizations, some of which had already been working for many years on separate aspects of subjects now subsumed under the environmental label. The World Meteorological Organization (WMO), for instance, had been dealing with atmospheric pollution, the World Health Organization (wHO) with environmental health, and the Food and Agricultural Organization (FAO) with the conservation of soil, forest, and animal resources. ${ }^{243}$ To further complicate things, unlike most subjects dealt by the UN, the environment was not just another separate sectoral issue, but rather a system of interacting relationships that extends through all

240 Institute on Man and Science, International Organization and the Human Environment: Proceedings of an International Conference, Rensselaerville, N.Y., May 1971.

241 Maurice F. Strong, Lecture delivered at Carlton University, Ottawa: Development, Environment and the New Global Imperative-The New Technological Order (1970-1) (on file with the Environmental Science and Public Policy Archives at Harvard University, Maurice F. Strong Papers, Box 29[292]).

242 See e.g. the view advanced by George Kennan that the United Nations was not the proper forum for dealing with environmental problems while a better solution would be the creation of an environmental agency run by developed countries, given that these problems were mainly caused by ten of the world's most industrialized countries. George F. Kennan, 'To Prevent a World Wasteland: A Proposal', 48(3) Foreign Affairs, Apr. 1970, 401-413.

243 Richard N. Gardner, 'The Role of the UN in Environmental Problems' (1972) 26(2) International Organization 237, 245. 
sectors of activity. ${ }^{244}$ As a result, the view was largely shared that, in order to avoid wasteful duplications, it would have been more efficient to rely on the already existing machinery than to create a whole new specialized agency or operating body: all functions which could best be performed by existing organizations should be assigned to those organizations. To be able to give the necessary weight to the environmental context as a whole, what was necessary was the creation, next to the existing machinery, of a body or a system able to coordinate the environmental activities of the different UN agencies.

After those three days of intense discussions, an international workshop was organized in Aspen during the following summer, which produced a set of general institutional recommendations. ${ }^{245}$ On this basis, a secretariat paper was completed at the end of the year and sent to Governments, before being considered at the final meeting of the Preparatory Committee in March 1972.. ${ }^{246}$ The result was the creation of UNEP, which would influence the activities of other organizations, promote international cooperation on environmental matters, provide general policy guidance, and constantly keep under review the world environmental situation. ${ }^{247}$

The same approach was adopted when discussing whether to establish an international environmental court. ${ }^{248}$ Once again, in the end, efficiency prevailed: to avoid wasteful duplications, it was deemed sufficient to be able to bring environmental disputes to any of the already existing courts, depending on the parties and the subject matter involved. None of these fora, however, had a truly environmental mandate or expertise and, when the chips were down, while they would take environmental factors into account, there could on occasion be a real conflict between their primary responsibilities and their consideration of the environment.

\subsection{The Environment as an 'Add-On': The Origin of the Nexus}

The chronological unfolding of the events that led to the creation of the trade and environmental regimes contributed greatly to the way in which their

\footnotetext{
244 The UN organizations have been created on the traditional sectoral pattern which had been developed, and still prevails, in most national governments. United Conference on the Human Environment, The UN System and the Human Environment, A/coNF.48/12 (Dec. 17, 1971).

245 International Institute for Environmental Affairs, 'The Human Environment: Science and International Decision-Making' (1971).

246 Gardner, 'The Role of the UN' (n 243) 243.

247 UNEP was created with G.A. Res. 2997 (XXVII) of December 15, 1972. See Article II.2 for the list of tasks and responsibilities of the Governing Council of UNEP.

248 Jessup, 'Do New Problems Need New Courts?' (n 170).
} 
relationship was perceived. The norms and institutions of international trade are rooted in a legal order established decades before environmental protection began to be considered and valued at the global level. When James Meade traveled to Washington to discuss future trade cooperation with Harry Hawkins and all the other members of the State Department, no one even thought of discussing the environment. Their mandate was itself limited to trade and economic objectives. ${ }^{249}$ Similarly, the drafters of the GATT could not have envisioned the types of environmental problems that would be addressed 25 years later in Stockholm, or the role that trade measures would have played in that context. Their one and only goal, instead, was to address international economic problems and, most important of all, to avoid protectionist revivals by diminishing trade barriers and encouraging the expansion of commerce. ${ }^{250}$

As a matter of fact, the international legal framework established in the 1940 s by the actors described in the first part of this chapter had been designed to guarantee peace and economic cooperation. The environment came later and was 'added' to this framework, thanks to the work and vision of equally brilliant individuals.

The world of international law and relations that had developed during the twentieth century soon appeared to work on a 'first come, first served' basis: economic matters ruled the roost and the environment could be regulated only to the extent permitted by economic considerations and only as long as it did not produce any detrimental effects on inter-state trade flows. The result was that the need to protect commerce from undue burdens overrode any environmental protection concerns: la libertè du commerce had become the overarching rule, and environmental protection merely the exception.

249 See i.e. the list of "overall and principal trade negotiating objectives of the United States", 19 U.S.C. $§ 2901(b), 2397$ note.

250 GATT, GATT Activities in 1960-61 (Geneva, June 1962). 